\title{
Sources and Effects of Fluids in Continental Retrograde Shear Zones: Insights from the Kuckaus Mylonite Zone, Namibia
}

\author{
C. A. Stenvall $\mathbb{D}^{1}{ }^{1}$ A. Fagereng, ${ }^{1,2}$ J. F. A. Diener, ${ }^{2}$ C. Harris, ${ }^{2}$ and P. E. Janney ${ }^{2}$ \\ ${ }^{1}$ School of Earth \& Ocean Sciences, Cardiff University, UK \\ ${ }^{2}$ Department of Geological Sciences, University of Cape Town, Private Bag X3, Rondebosch 7701, South Africa
}

Correspondence should be addressed to C. A. Stenvall; stenvallca@cardiff.ac.uk

Received 31 October 2019; Revised 6 May 2020; Accepted 21 May 2020; Published 1 August 2020

Academic Editor: Paul D. Bons

Copyright $\odot 2020$ C. A. Stenvall et al. This is an open access article distributed under the Creative Commons Attribution License, which permits unrestricted use, distribution, and reproduction in any medium, provided the original work is properly cited.

\begin{abstract}
Midcrustal rocks in retrograde metamorphic settings are typically $\mathrm{H}_{2} \mathrm{O}$-undersaturated and fluid-absent and have low permeability. Exhumed continental retrograde faults, nonetheless, show evidence for the operation of fluid-mediated weakening mechanisms during deformation at midcrustal conditions. To explore the origin and effects of fluids in retrograde faults, we study the Kuckaus Mylonite Zone (KMZ), an exhumed crustal-scale, strike-slip shear zone in the southern Namibian Namaqua Metamorphic Complex. The KMZ deformed quartzofeldspathic migmatised gneisses at midcrustal retrograde conditions $\left(450-480^{\circ} \mathrm{C}, 270-420 \mathrm{MPa}\right)$ in the Mesoproterozoic, $40 \mathrm{Ma}$ after granulite facies peak metamorphism at $825^{\circ} \mathrm{C}$ and $550 \mathrm{MPa}$. The mylonites contain fully hydrated retrograde mineral assemblages, predominantly adjacent to anastomosing high-strain zones, providing evidence of local $\mathrm{H}_{2} \mathrm{O}$ saturation and fluid presence during deformation. Whole rock and quartz vein $\delta^{18} \mathrm{O}$ values suggest that at least some of the fluids were meteoric in origin. The rocks across the shear zone retain the effect of different protoliths, implying little effect of fluid-rock interaction on whole rock major element chemistry. Together with a general scarcity of quartz veins, this suggests that fluid/rock ratios remained low in the KMZ. However, even small amounts of $\mathrm{H}_{2} \mathrm{O}$ allowed reaction weakening and diffusion-precipitation, followed by growth and alignment of phyllosilicates. In the ultramylonites, a fine grain size in the presence of fluids allowed for grain size sensitive creep. We conclude that the influx of even small volumes of fluids into retrograde shear zones can induce drastic weakening by facilitating grain size sensitive creep and retrograde reactions. In retrograde settings, these reactions consume fluids, and therefore elevated fluid pressures will only be possible after considerable weakening has already occurred. Our findings imply that the range of seismic styles recently documented at active retrograde transform faults may not require high fluid pressures but could also arise from other local weakening mechanisms.
\end{abstract}

\section{Introduction}

Given a range of assumptions, including constant fluid pressure $\left(P_{\mathrm{f}}\right)$, strain rate, and composition, increasing depth in the continental crust results in a pressure-dependent increase in the frictional strength of rocks and a thermally dependent reduction in viscous strength [1]. Therefore, the frictionalviscous transition theoretically represents the strongest part of the continental crust, but it is still poorly understood [2]. Deformation around the frictional-viscous transition is localised into shear zones, which may exert a major control on the strength of the lithosphere (e.g., [3-5]). The relative strength or weakness of a shear zone is, however, a complex puzzle, in which a combination of interconnected lithological, mechanical, and physical variables play a role. Traditionally, most studies of continental crustal rheology have focussed on quartz and feldspar (lithological variables), deforming by frictional sliding and/or dislocation creep (mechanical variables) over a range of pressures $(P)$, temperatures $(T)$, and $P_{\mathrm{f}}$ (physical variables; e.g., [6]). This is based on the assumption that quartz and feldspar are the two most abundant minerals in the continental crust, frictional sliding and dislocation creep are two dominant deformation mechanisms, and $P, T$, and $P_{\mathrm{f}}$ are the primary physical variables. Among these 
variables, fluids have a direct effect on the effective pressure as well as additional effects on the lithology through metamorphic reactions [7-9]. Fluids have also been associated with a number of weakening mechanisms such as (1) the breakdown of strong minerals into weaker minerals [8, 10, 11]; (2) grain size reduction by the nucleation of retrograde and replacement minerals $[8,12,13]$; (3) aiding diffusion creep and other grain size sensitive deformation processes [14-17]; (4) causing hydrolytic weakening in minerals deforming by dislocation creep [18, 19]; and (5) depending on permeability, fluid presence can reduce the effective normal stress by increasing fluid pressure [7].

Given the potential importance of fluids in shear zones, a related question pertains to the sources, volumes, and pathways exploited by these fluids. In prograde metamorphic settings, like subduction zones, the deforming lithologies themselves constitute the fluid source. Peacock [20] estimated that approximately $8.7 \times 10^{11} \mathrm{~kg}$ of bound $\mathrm{H}_{2} \mathrm{O}$, stored in the oceanic crust and overlying sediments, is subducted past the accretionary prism each year. Depending on the $P-T$ path of this subducting slab, the breakdown of hydrous minerals such as lawsonite, chlorite, or amphibole will release some of these fluids [20,21], causing locally elevated fluid pressures. This is well displayed in exhumed subduction melanges as abundant veining $[22,23]$ that may be the geologic product of episodic tremor and slow slip [24].

Contrary to prograde metamorphic settings, rocks in retrograde settings will have been previously dehydrated during higher-grade metamorphism. Under retrograde conditions, such rocks will consist of fluid-undersaturated mineral assemblages that are incapable of producing fluids through dehydration reactions but are capable of undergoing rehydration if external fluid addition was to occur [25-29]. Weakening simply due to elevated fluid pressures is therefore not generally applicable to explain the weakness of active retrograde faults [30, 31]. Exhumed active and inactive retrograde fault zones like the Median Tectonic Line (MTL; Japan; [32]), Karakoram (India; [33]), and Outer Hebrides Fault Zone (Scotland; [34]) do, nonetheless, display retrograde mineral assemblages, requiring at least some fluids to have played a role during deformation. Furthermore, a fluid presence at depth is commonly inferred for active retrograde faults based on geophysical observations [35-37]. Fluids are thereby likely to have an important role in the weakening occurring in retrograde settings, but their source, volume, and the specific mechanisms they facilitate remain unclear.

As locally produced fluids are unlikely in retrograde shear zones, external sources are required to explain fluid presence [38]. Depending on the tectonic setting, possible external sources include meteoric water (e.g., Alpine Fault; $[39,40]$ ), metamorphic dehydration of associated lithologies undergoing prograde metamorphism (e.g., SAFZ; [41, 42]), magma crystallisation or migration (e.g., MTL; [43]), and mantle degassing (e.g., SAFZ; [44]). Fluid volumes in previous studies on retrograde faults are mainly qualitative estimates and vary considerably from completely dry to large volumes of fluids $[28,34]$. For external fluids to be invoked, a permeable pathway between the fluid source and shear zone is required.
To explore the origin and effects of fluids in retrograde transform faults, we study an exhumed example, the Kuckaus Mylonite Zone in Namibia. This crustal-scale, strike-slip shear zone was active at midcrustal retrograde conditions $\left(450-480^{\circ} \mathrm{C}, 270-420 \mathrm{MPa}\right)$ in the Mesoproterozoic, $40 \mathrm{Ma}$ after granulite facies peak metamorphism $\left(825^{\circ} \mathrm{C}, 550 \mathrm{MPa}\right.$; [45-47]). Retrograde mineral assemblages, predominantly adjacent to local high-strain zones, provide evidence of fluid involvement during deformation [45]. By studying rocks from the $\mathrm{KMZ}$ we aim to answer the following three questions: (1) Where did the fluids come from? (2) What effect did they have on the lithological aspects that may influence the strength of the shear zone? (3) Did fluids also facilitate weakening by increasing $P_{\mathrm{f}}$, as is often inferred in active shear zones? To address the first question, oxygen isotope compositions of quartz veins, mylonites, and wall rocks are used to consider possible fluid sources [48-50]. To assess the lithological effects the fluids had on the shear zone, isocons, constructed using major element concentrations, have been used together with microstructural observations to assess what retrograde and replacement reactions occurred in the system as well as to estimate mass changes, induced by fluid flow, across the shear zone $[51,52]$. Aided by microstructural observations, we finally discuss the results and their interdependent nature to determine which weakening mechanisms, associated with the introduction of fluids, were dominant during shearing in the KMZ.

\section{Geological Setting}

The KMZ is part of the Marshall Rocks-Pofadder shear zone system (MRPSZ), a subvertical NW-SE striking, dextral, shear zone that extends for $550 \mathrm{~km}$ across Namibia and South Africa (Figure 1; $[46,47]$ ). In the study area, the MRPSZ is localised in rocks of the Aus Domain, separated to the south from the Richtersveld and Bushmanland Subprovinces by the Southern Namaqua Front, and to the north from the Konkiep Subprovince by the Lord Hill-Excelsior Shear Zone [53]. These subprovinces and domains constitute the northwestern part of the Namaqua Metamorphic Complex (NMC). The NMC is bound to the south by rocks of the younger Saldania belt, and to the north by the Kalahari Craton. The central parts are covered by the Karoo Supergroup, with exposures limited to the western and eastern coasts of southern Africa ([54]).

The tectonostratigraphy of the rocks of the Aus Domain is believed to consist of both reworked 2000-1700 Ma basement and younger 1250-1100 Ma supracrustal and igneous rocks $[55,56]$. The supracrustals belong to the Garub sequence, whereas three intrusive suites have been identified in the mapping area $[46,56]$. The first voluminous igneous suite is the Tsirub Gneiss, a garnet-bearing tonalitic to granodioritic augen gneiss, whereas the other igneous suite is an unnamed and undifferentiated biotite gneiss that is made up of K-feldspar, plagioclase, quartz, and biotite [46]. Apart from these two volumetrically dominant gneisses, the mapped area contains scattered bodies of leucogranites, comprising megacrystic K-feldspar and quartz, with minor biotite and garnet $[46,47,56]$. 


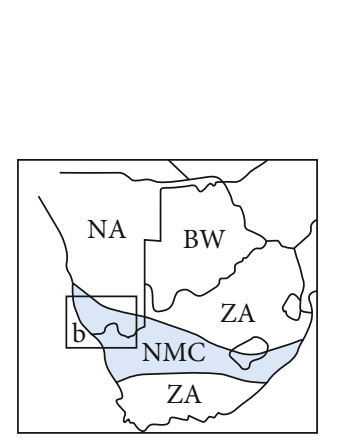

(a)

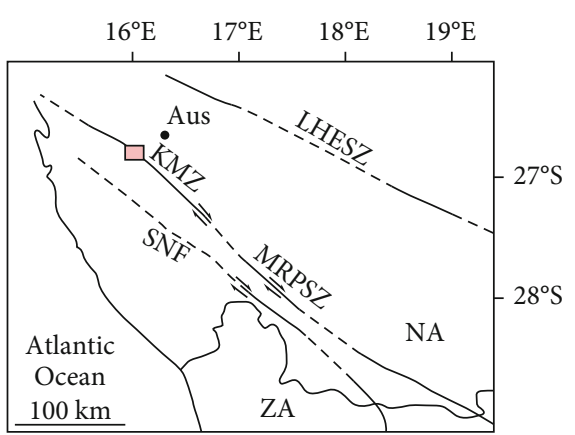

(b)

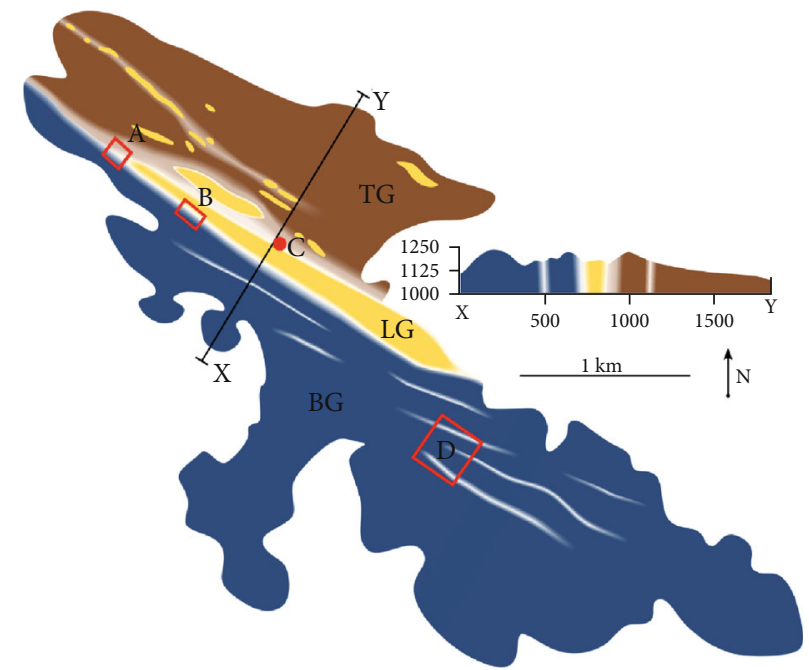

(c)

Figure 1: Geological setting of the Kuckaus Mylonite Zone (KMZ) in the Namaqua Metamorphic Complex (NMC) of southern Africa (a). The KMZ is part of the Marshall Rocks-Pofadder shear zone system (MRPSZ), subparallel to the Southern Namaqua Front (SNF) and the Lord Hill - Excelsior Shear Zone (LHESZ) (b). In the study area, the KMZ is exposed over a 2 by $5 \mathrm{~km}$ area (shape of mapped area is a function of Quaternary sands coverage), with Tsirub Gneiss (TG) in the NE, the main leucogranite (LG) bodies in the middle, and biotite gneiss (BG) in the SW (c). Strain is heterogeneously distributed over 1-2 km (same strain gradient key as in Figure 2). Red boxes show locations of areas A-D in Figure 2.

The NMC is a metamorphic belt associated with the formation of Rodinia in the Namaqua orogeny, with hightemperature-low-pressure peak metamorphism at 1200$1050 \mathrm{Ma}$ [46]. The biotite gneiss and Tsirub Gneiss have experienced the same tectonometamorphic history, both preserving migmatitic textures. They were subsequently deformed during the later stages of the Namaqua orogeny under retrograde midcrustal conditions at $270-420 \mathrm{MPa}$ and $450-480^{\circ} \mathrm{C}$ [45], $40 \mathrm{Ma}$ after peak granulite facies metamorphism at $550 \mathrm{MPa}$ and $825^{\circ} \mathrm{C}$, c. $1065-1045 \mathrm{Ma}$ [56]. Most leucogranite bodies within the study area behaved as more competent units than the surrounding gneisses, and are thereby inferred as prekinematic; however, some minor leucogranite bodies show evidence of shear-zone-parallel liquid-state flow suggesting synkinematic intrusion [47].

In the study area, the KMZ is manifested as an approximately $1-2 \mathrm{~km}$ wide zone of heterogeneously distributed strain, separating the Tsirub Gneiss in the NE from the biotite gneiss in the SW (Figure 1; [47]). The largest leucogranite body ( $\sim 2000 \mathrm{~m}$ long, $<200 \mathrm{~m}$ wide) is located between the biotite gneiss and Tsirub Gneiss, with its long axis aligned parallel to the shear zone margins. Smaller leucogranite bodies, with long axes down to a few $\mathrm{m}$, can be found at scattered locations in the Tsirub Gneiss [47]. The leucogranite bodies, together with gneissic lozenges ranging in size from $\mathrm{m}$ to tens of $\mathrm{m}$ wide, form low-strain zones around which the strain is heterogeneously distributed. The mylonitic fabric is predominantly subvertical, striking NW-SE, with a subhorizontal lineation [47]. The highest-strained rocks are localised into narrow ultramylonites which can be a few tens of $\mathrm{cm}$ wide [57].

As a big proportion of the strain is localised around the central leucogranite body, three areas around it were chosen for more detailed study, one at the nortwestern tip and two on either side (Figures 1 and 2). A fourth location was chosen within the biotite gneiss, where strain is heterogeneously distributed around low-strain lozenges into anastomosing, thin (tens of $\mathrm{cm}$ wide), ultramylonite zones, within broader mylonites (Figures 1 and 3). 

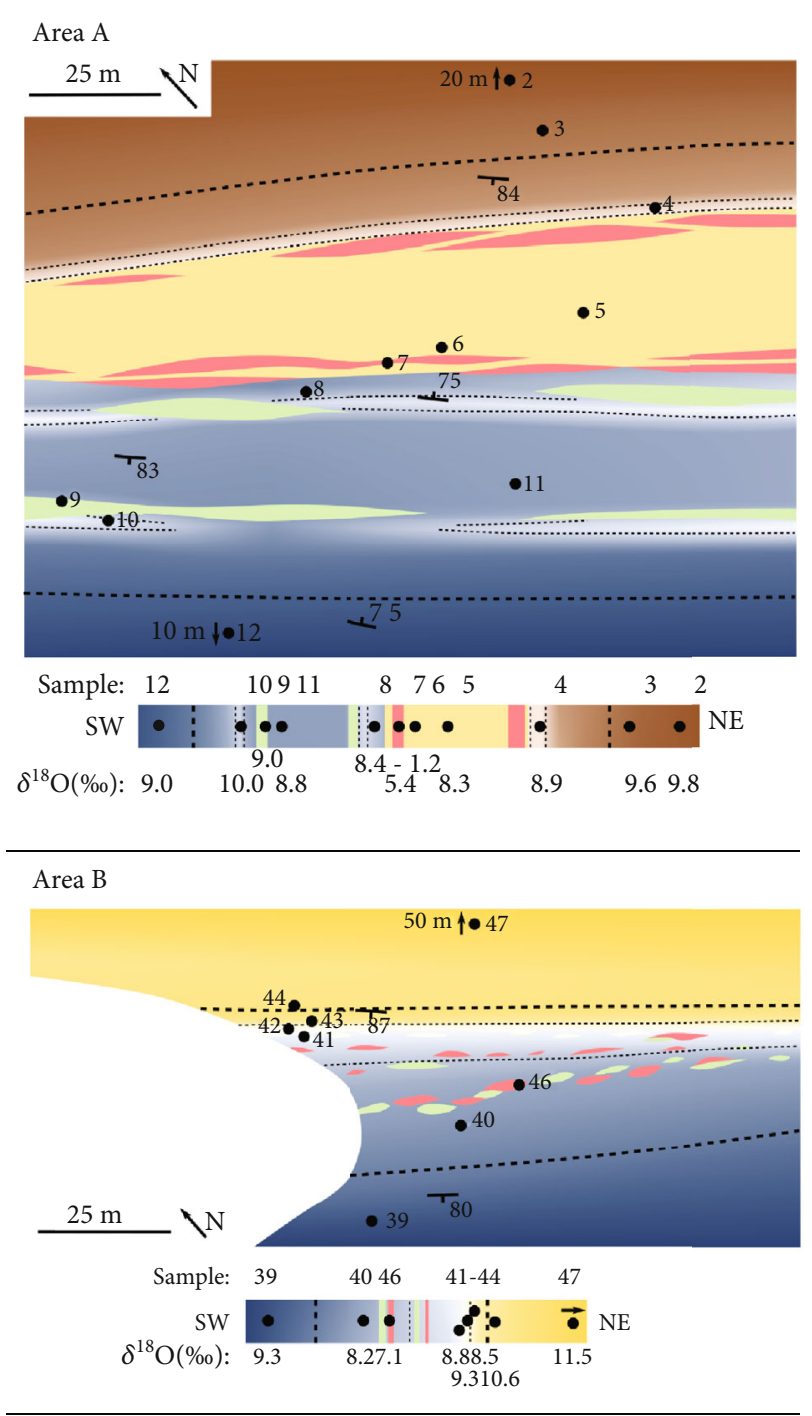

\begin{tabular}{rrrrrr}
\hline Area C & & & & & \\
Sample: & 35 & 3433 & 32 & 31 \\
$\mathrm{SW}(0 \mathrm{~m})$ & $\bullet$ & $\bullet$ & $\bullet$ & $\bullet$ & $\bullet \mathrm{NE}(10 \mathrm{~m})$ \\
$\delta^{18} \mathrm{O}(\% \mathrm{o}):$ & 12.6 & 12.111 .8 & 11.5 & 13.1 \\
\hline
\end{tabular}

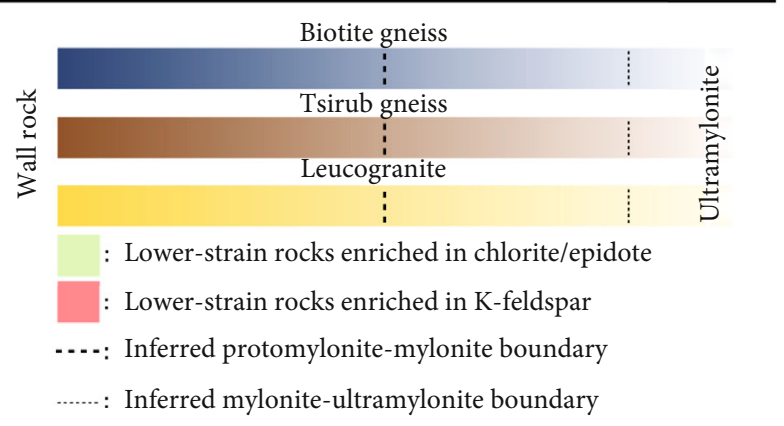

Figure 2: Maps of the studied areas (A-C) within the KMZ. Maps include locations of sampled rocks and their $\delta^{18} \mathrm{O}$ values. Rock descriptions and GPS locations can be found in Table S1.

\section{Outcrop Descriptions}

From west to east, the four areas chosen for more detailed study were assigned letters A-D. Area A covers the NW tip

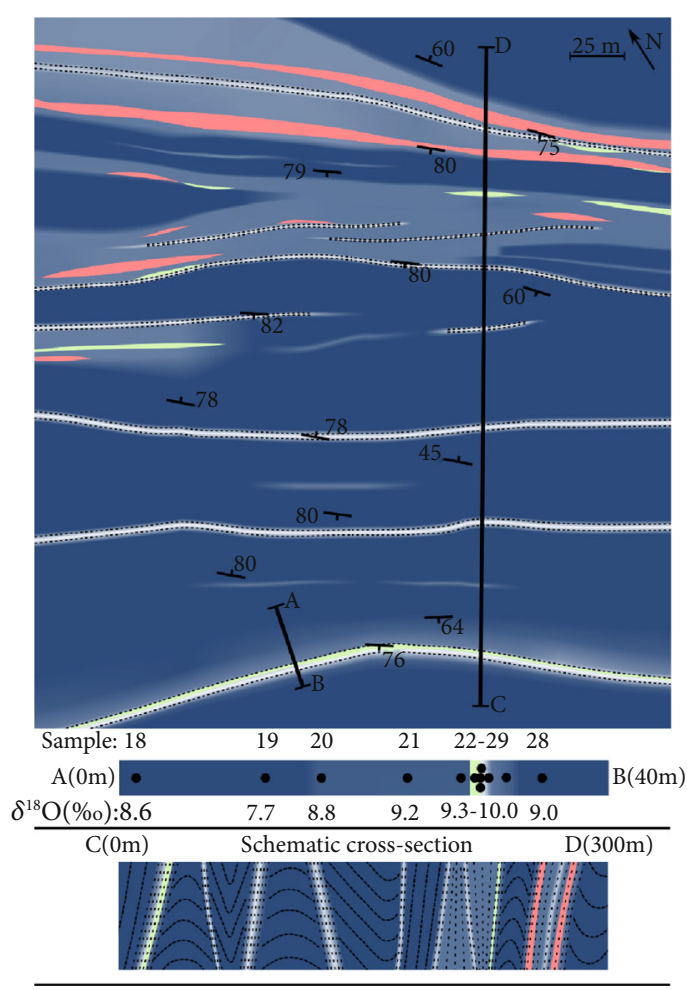

Figure 3: Map of area D, including the sampled transect (A-B) with sample locations and $\delta^{18} \mathrm{O}$ values and schematic cross-section (C-D). Colours are the same as in Figure 2. Dashed lines on the map marks the boundary between protomylonite and mylonite. The ultramylonites are too thin to mark with dashed lines. Rock descriptions and GPS locations can be found in Table S1.

of the central leucogranite body. Areas B and C are located on either side of the central leucogranite body, with B transitioning into the biotite gneiss and $\mathrm{C}$ into the Tsirub Gneiss (Figure 1(c)). Area D is located within the biotite gneiss, where multiple low-strain lozenges are surrounded by anastomosing high-strain zones (Figure 3 ).

3.1. Area A. Strain is heterogeneously distributed over a $\sim 140 \mathrm{~m}$ wide shear zone, juxtaposing Tsirub Gneiss to the $\mathrm{NE}$ and the biotite gneiss to the SW (Figure 2). The gneissose fabric of the Tsirub Gneiss dips steeply $\left(>80^{\circ} \mathrm{SW}\right)$, whereas the migmatitic fabric of the biotite gneiss is more irregular, in places tightly folded with subvertical limbs and subhorizontal hinge lines.

The mylonitic fabric dips predominantly $>80^{\circ} \mathrm{SW}$; however, local variations range between $75^{\circ} \mathrm{SW}$ and $75^{\circ} \mathrm{NE}$. The lineation plunges gently $\left(<10^{\circ}\right)$ to the SE. The features described here are continuous along strike, at the scale of the exposure, if not otherwise stated.

The transition from wall rock to protomylonite and further to mylonite is gradual, over a distance of $\sim 30 \mathrm{~m}$ in the biotite gneiss and over $\sim 50 \mathrm{~m}$ on the Tsirub Gneiss side. The transition from mylonite to ultramylonite is a sharper, gradual transition, occurring over $<10 \mathrm{~cm}$ and defined by a drastic grain size decrease (Figure 4(b)). Apart from the two ultramylonite zones transitioning NE and SW into the Tsiruband biotite gneisses, respectively, a third ultramylonite zone 


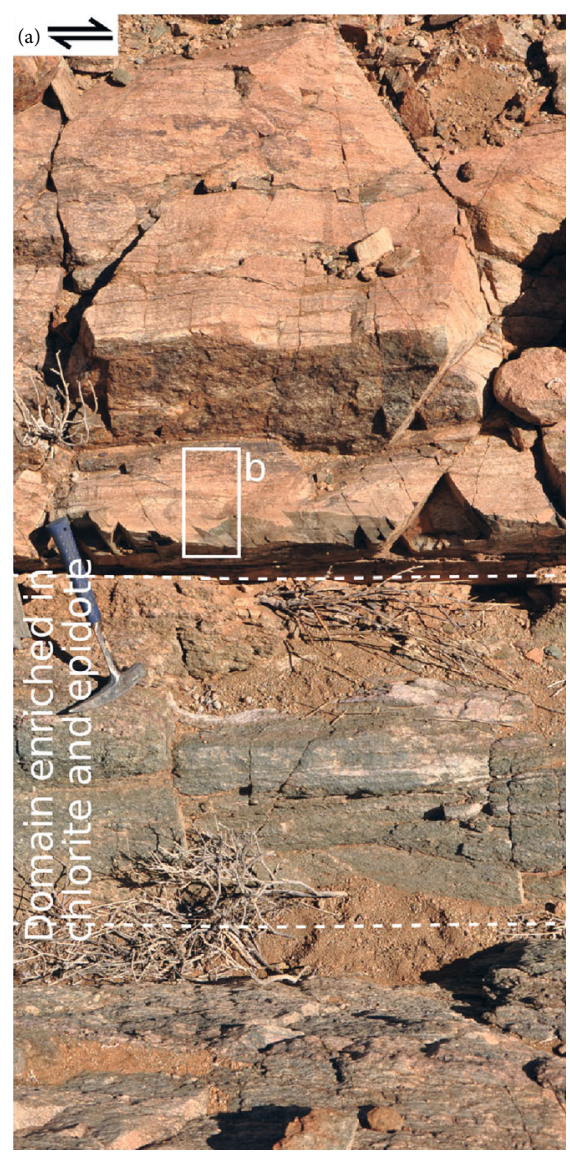

(a)

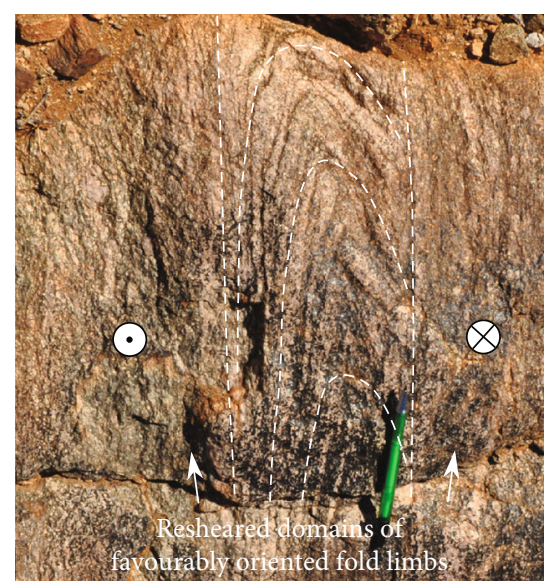

(c)

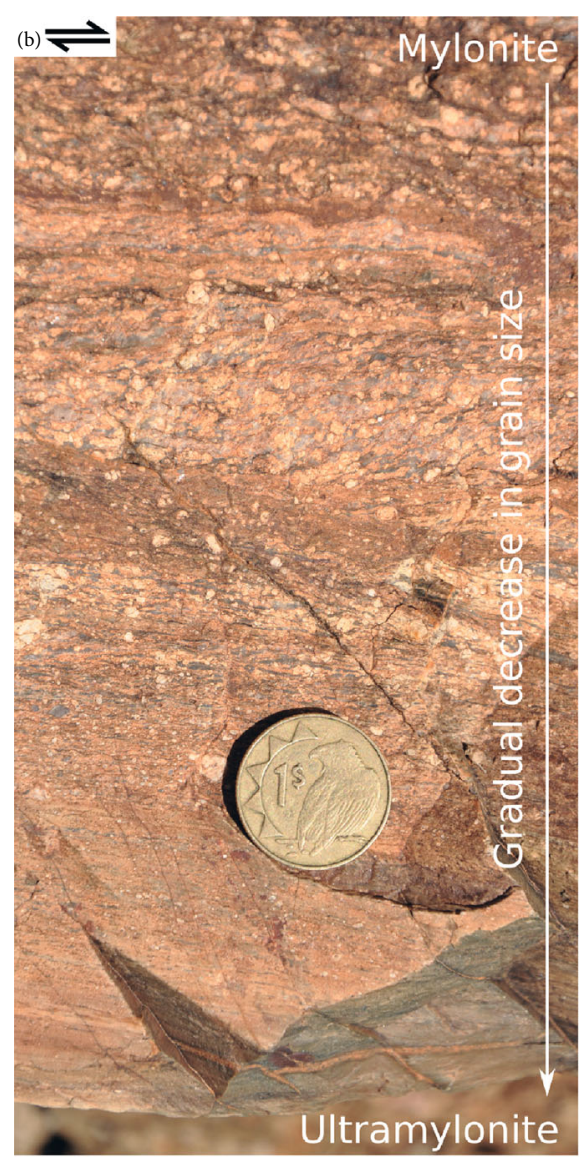

(b)

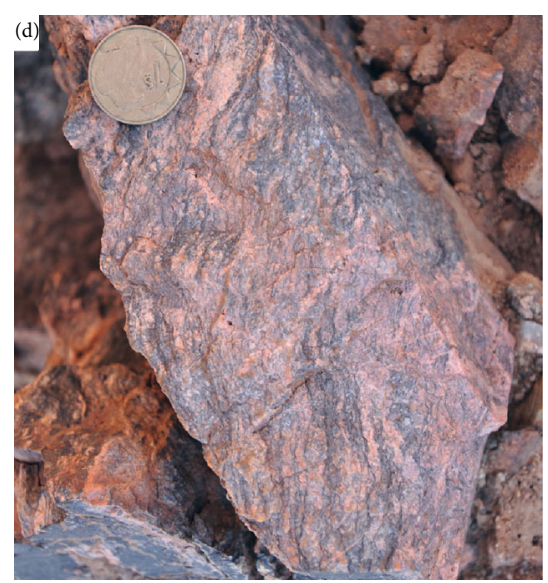

(d)

Figure 4: Continued. 


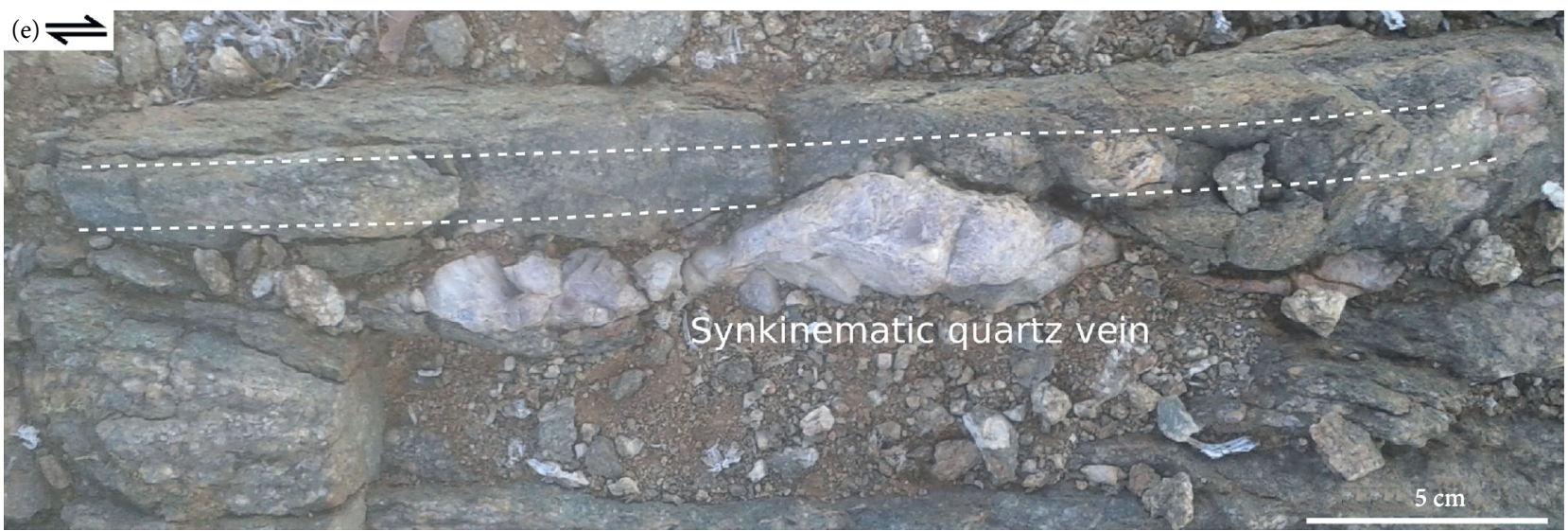

(e)

FIGURE 4: Outcrop pictures of (a) the core region of the sampled high-strain zone in area D, including a representative (green) zone enriched in chlorite and epidote; (b) gradual but sharp transition from mylonite to ultramylonite; (c) reshearing of fold limbs in the migmatitic biotite gneiss in area D; (d) representative (pink) sample enriched in feldspar; (e) representative synkinematic quartz vein.

occurs halfway between the first two, separating two $\sim 30 \mathrm{~m}$ wide less deformed domains. All three ultramylonite zones are 1-2 $\mathrm{m}$ wide, but contain lower-strain elongate pods in places, resulting in thinner, anastomosing, tens of $\mathrm{cm}$ wide ultramylonite bands. The southwesterly domain between the ultramylonites is made up of mylonitic biotite gneiss, whereas the northeasterly domain comprises rocks of granitic composition and texture. The former depicts a mylonitic fabric throughout its width, while the latter, on the other hand, is only sheared along its edges, with its central parts displaying a less orderly nature, coarser grain sizes, with a mixture of brittle tensile and shear fractures with a weak ductile overprint and minor ductile shear zones.

All three ultramylonite zones are bordered by zones that show an increased abundance of medium- to coarse-grained chlorite and epidote or K-feldspar, resulting in different shades of green and pink (Figures 2, 4(a), and 4(d)). These zones, located at or near the greatest strain gradients in the shear zone, exhibit a less developed mylonitic fabric than the adjacent mylonites, however, in the same orientations. The zones are elongate parallel to the general strike of the shear zone, with ellipsoidal pods ranging in along-strike length from a few meters up to $\sim 100 \mathrm{~m}$.

3.2. Area B. Area $B$ covers an area with the central leucogranite body to the NE and with the biotite gneiss to the SW (Figure 2). Here, the dip of the mylonitic fabric increases progressively from $80^{\circ}$ in the SW to vertical in the NE with a subhorizontal lineation plunging gently $\left(<10^{\circ}\right)$ to the SE. The overall strain distribution shows the most strained rocks closest to the boundary between the two lithologies. But whereas only the outermost $\sim 15 \mathrm{~m}$ of the leucogranite is mylonitised, the biotite gneiss is more widely affected by shearing, with the unsheared wall rock occurring outside the mapped area.

The least strained biotite gneisses in area B are thereby protomylonites, grading into mylonites over a few $\mathrm{m}$ approximately $35 \mathrm{~m} \mathrm{SE}$ of the boundary between the biotite gneiss and the leucogranite. The mylonite zone tapers slightly towards the SE. The transition to ultramylonite occurs $\sim 15 \mathrm{~m}$ SW of the boundary between the biotite gneiss and the leucogranite. The ultramylonite is dark brown in colour with an extremely fine grain size. Lower-strain elongate lozenges are scattered within the ultramylonite; they do not, however, crosscut the mylonitic fabric. At the mylonite to ultramylonite transition, these lozenges are up to $\sim 8 \mathrm{~m}$ long and a few meters wide (Figure 2). With decreasing distance from the boundary between biotite gneiss and leucogranite, the aspect ratio of the lozenges becomes larger and the long axes become more uniformly parallel to the mylonitic fabric. The boundary between the biotite gneiss and the leucogranite is marked by a distinct shift in colour to a paler brown and further to a more pink colour. In only a few $m$, the grain size increases with the transition to mylonite and further to protomylonite approximately $10 \mathrm{~m}$ from the boundary. $15 \mathrm{~m}$ from the boundary to the biotite gneiss, the leucogranite displays a phaneritic texture.

The $5 \mathrm{~m}$ closest to the boundary on the NE (leucogranite) side depicts a clear reduction in quartz content, and the feldspar appears more fractured compared to further away from the local high-strain core. On the SW (biotite gneiss) side of the transition on the other hand, similarly to area $\mathrm{A}$, there are lozenges characterised by a coarser grain size than the ultramylonite that hosts them. These lozenges consist of either a mixture of quartz and K-feldspar or chlorite and epidote. The biotite gneiss mylonites are distinctly richer in K-feldspar than the biotite gneiss protomylonite and host few, scattered, mutually crosscutting veins. The veins display a massive texture of either quartz, K-feldspar, or a mixture of the two, and are up to $10 \mathrm{~cm}$ in thickness. They dip steeply $\left(>75^{\circ}\right)$ both to the SW and NE, and whereas some were found parallel to the mylonitic fabric, most cross-cut it to follow a slightly more N-S strike.

3.3. Area C. On the northeastern side of the central leucogranite body, the strain is, similar to area B, localised against the leucogranite body and manifested as a steeply dipping foliation $\left(>70^{\circ}\right)$. Contrary to area $\mathrm{B}$, here the local high-strain zone constitutes the boundary between the leucogranite and 
the Tsirub Gneiss and dips to the NE. The lineation is again plunging gently $\left(<10^{\circ}\right)$ to the SE. The high-strain zone has irregular boundaries but is approximately $8 \mathrm{~m}$ wide, with up to $50 \mathrm{~cm}$ thick ultramylonite at its core (Figure 2). The transition from ultramylonite to mylonite, defined by a grain size reduction, occurs sharper than in the previous areas, over a few $\mathrm{cm}$. The transitions from mylonite to protomylonite and further into wall rock occur progressively over $\sim 5 \mathrm{~m}$ on both sides. Area $\mathrm{C}$ does not contain zones with an increased abundance of chlorite, epidote, or K-feldspar.

3.4. Area $D$. Area $\mathrm{D}$ covers an area in the biotite gneiss where the strain is heterogeneously distributed with high-strain zones separating lozenges of migmatitic biotite gneiss (Figure 3). The short axes of the lozenges are up to $75 \mathrm{~m}$, with the long axes mostly stretching across the entire mapped area $(\sim 250 \mathrm{~m})$ in a NW-SE direction, with a few pinching out within it. The orientation of the mylonitic fabric in the high-strain zones is more varied than in the previously described areas, ranging from $>60^{\circ} \mathrm{SW}$ to $>75^{\circ} \mathrm{NE}$; however, the strike is fairly constant, NW-SE. The lineation is plunging steeper than in previous areas, however, again gently at $<20^{\circ}$. The leucosome and melanosome layers ( $\mathrm{mm}$ to $<5 \mathrm{~cm}$ thick) making up the migmatitic fabric in the lozenges are tightly folded in parasitic to larger, tight to open, folds with amplitudes of tens of $\mathrm{m}$. The hinge lines of these folds are, similarly to the lineation, plunging gently $\left(<20^{\circ}\right)$ to the SE. Area D additionally contains a few scattered locations where brittle deformation occurs over elongate domains up to a few $\mathrm{m}$ in length, parallel to strike, and tens of $\mathrm{cm}$ wide. These domains are overprinted by ductile deformation.

The anastomosing high-strain zones are predominantly continuous along strike and vary in thickness from tens of $\mathrm{cm}$ to $\sim 50 \mathrm{~m}$. They occur predominantly where fold limbs, of the larger amplitude folds, are oriented subparallel to the general orientation of the local shear zone boundaries (Figure 3). Preferential reshearing of the parasitic fold limbs is also apparent at outcrop scale (Figure $4(\mathrm{c})$ ). The relative thicknesses of protomylonite, mylonite, and ultramylonite in these zones vary along strike and from one high-strain zone to the next; however, even the thinnest $\sim 10 \mathrm{~cm}$ high-strain zones commonly comprise ultramylonite at their cores, resulting in sharp transitions from migmatitic wallrock to ultramylonite. The transitions are, like in the previous areas, defined by a grain size reduction with gradual boundaries.

Area $\mathrm{D}$ also contains zones similar in nature to the ones in areas $\mathrm{A}$ and $\mathrm{B}$, pink or green in colour, comprising higher concentrations of K-feldspar or chlorite and epidote with a coarser grain size than the surrounding mylonites. These zones are elongated parallel to the mylonitic fabric, have irregular thicknesses from $10 \mathrm{~cm}$ to $10 \mathrm{~m}$, and range in length from a few $m$ to continuous across the mapped area. They are typically located along the greatest strain gradients adjacent to the ultramylonites (Figure 4(a)).

The sampled high-strain zone is representative of the high-strain zones in area D. It strikes NW-SE with a dip of $\sim 60^{\circ} \mathrm{SW}$ and contains a $\sim 10 \mathrm{~cm}$ thick ultramylonite core, continuous over the mapped area, which gradually transitions to mylonite over a few $\mathrm{cm}$ (Figure 4(b)). The ultramylo- nitic core is bordered on either side by a $\sim 5 \mathrm{~m}$ thick, gradual, mylonite to protomylonite transition zone, followed by a gradation to a background unsheared migmatitic fabric over the next few $\mathrm{m}$. A $1 \mathrm{~m}$ wide area of the mylonite on the northern side of the ultramylonite shows an increased concentration of chlorite. The zone, clearly distinguishable from the wider mylonites by its green colour and coarser grain size (Figure 4(a)), follows the boundary of the ultramylonite.

\section{Microstructures}

Diener et al. (2016) suggested that strain localisation in the $\mathrm{KMZ}$ was achieved by the growth of weak retrograde mineral phases as well as grain size reduction, both facilitated by a fluid presence. Whereas increased K-feldspar, chlorite, and/or epidote abundance is typical adjacent to ultramylonites, this association is not present within the ultramylonites themselves. On the outcrop scale, the increase in K-feldspar, chlorite, and/or epidote content does not therefore correlate with strain intensity, but rather with strain gradients, more specifically the narrow transitions from mylonite to ultramylonite (Figure 4(b)). For a more comprehensive study of the controls on strain localisation, effects of fluids, and the deformation mechanisms that were active in the KMZ, bulk rock samples were collected from all four areas. Samples were typically 10 to tens of $\mathrm{cm}$ in the shortest dimension, and were collected along transects, roughly perpendicular to strike, wherever changes in lithology or strain intensity occurred, causing the spacing between samples to vary (Figures 2 and 3). This approach inevitably leads to a sampling bias with higher-strained rocks being overrepresented; however, it provides the best opportunity to compare the results between the different lithologies and with changes in strain. Oriented thin sections were prepared in the Department of Geological Sciences at the University of Cape Town, cut perpendicular to foliation and parallel to stretching lineation.

4.1. Wall Rocks and Protomylonites. The different protoliths contain feldspar, quartz, biotite, muscovite, chlorite, amphibole, and accessory minerals including apatite, rutile, titanite, and zircon. Feldspar porphyroclasts are up to $4 \mathrm{~mm}$ in all low-strain examples except for the Tsirub Gneiss, where the grain size is $<2 \mathrm{~mm}$. Many feldspar porphyroclasts are fractured, some of which display shear displacement in, for example, bookshelf-type microstructures (Figure 5(a)). Most porphyroclasts are subrounded; however, angular and rounded porphyroclasts are also present (Figures 5(a)5(d)). Furthermore, the porphyroclasts display extensive microcracking, deformation twinning, and patchy undulose extinction (Figures 5(a)-5(d)). Feldspar is also present as neoblasts $<20 \mu \mathrm{m}$, between fractures and in stress shadows (Figures 5(a)-5(d)). Quartz is present in discontinuous ribbons that range from a few grains wide to $\sim 1 \mathrm{~mm}$ thick. Quartz grain sizes range from $\sim 10 \mu \mathrm{m}$ where they are pinched between feldspar porphyroclasts to $\sim 200 \mu \mathrm{m}$ where the ribbons are thickest. The ribbon quartz display a strong CPO [57]. Quartz is also found filling fractures in feldspar porphyroclasts and as neoblasts in their stress shadows (Figures 5(a) and 5(c)). Phyllosilicates are mostly fine grained $(<50 \mu \mathrm{m})$ and aligned parallel to foliation where they were not 


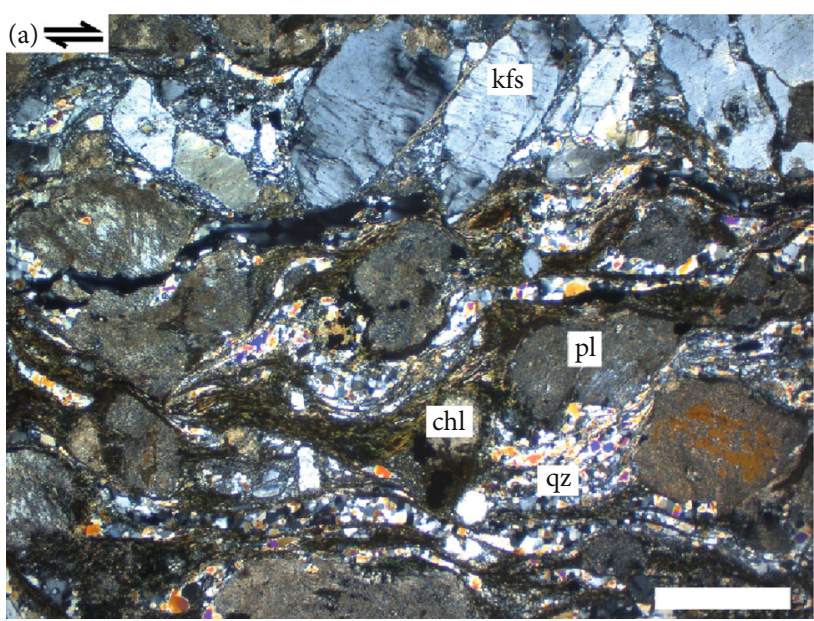

(a)

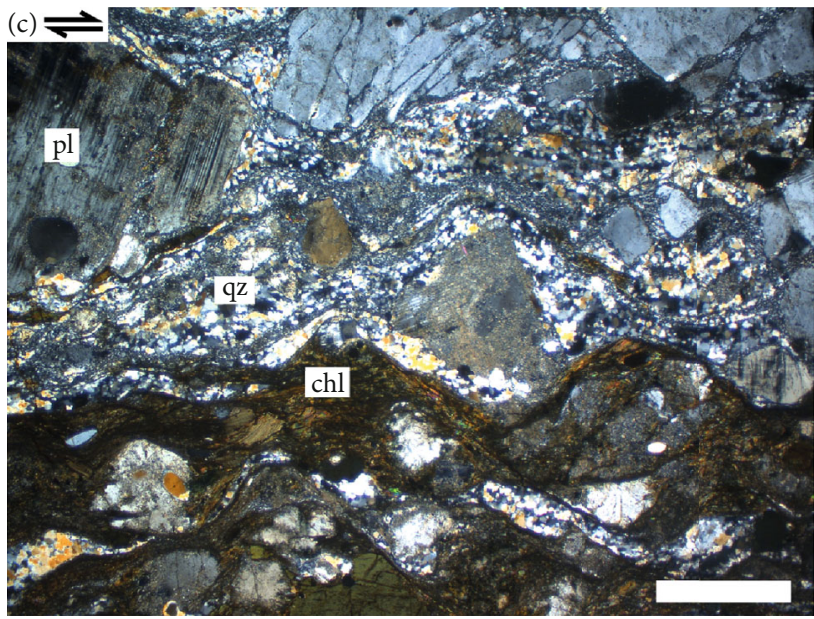

(c)

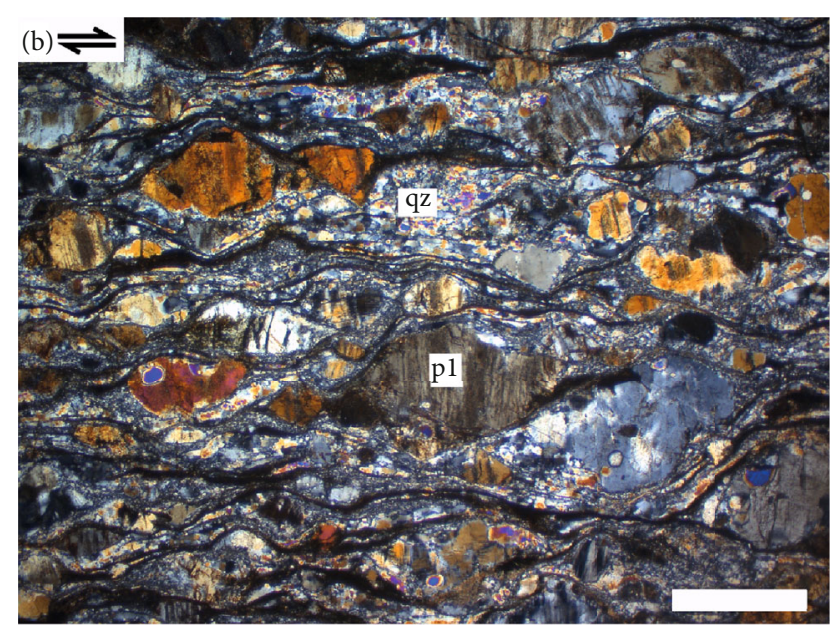

(b)

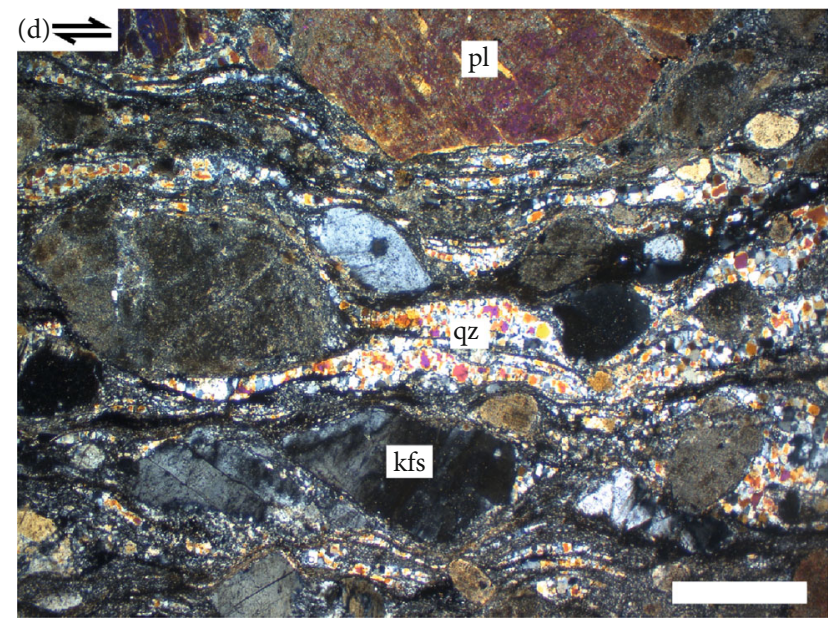

(d)

FIGURE 5: Representative photomicrographs of protomylonites from the KMZ. Feldspar porphyroclast contain both tensile and shear fractures, and plagioclase is heavily sericitized. Quartz is found in discontinuous ribbons with a range of grain sizes $(\sim 10-200 \mu \mathrm{m})$, defining the mylonitic foliation in conjunction with the phyllosilicates. (a) Sample 29, biotite gneiss, from area D. (b) Sample 2, Tsirub Gneiss, from Area A. (c) Sample 12, biotite gneiss, from area A. (d) Sample 35, leucogranite, from area C. White bars $=1 \mathrm{~mm}$.

obstructed by feldspar porphyroclasts, and much like quartz, phyllosilicates are found filling feldspar porphyroclast fractures and in their stress shadows. The neoblasts in the porphyroclast stress shadows all show low degrees of internal strain [57]. Sericite flakes also occur within the plagioclase grains. Some phyllosilicates are, however, found in larger grain sizes ( $1 \mathrm{~mm})$, namely chlorite, which is also one of the major differences between the separate protoliths. Chlorite is found in the highest amounts in the biotite gneiss, followed by the Tsirub Gneiss, and is absent in the leucogranite. In the biotite gneiss, chlorite is found enveloping feldspar porphyroclasts and stretched out from their stress shadows, forming in places thicker $\sim 1 \mathrm{~mm}$ bands (Figures 5(a) and 5(c)). In the Tsirub Gneiss, chlorite is found with other fine-grained $(<30 \mu \mathrm{m})$ phyllosilicates in thinner $(<100 \mu \mathrm{m})$ seams, parallel to the foliation.

4.2. Mylonites and Ultramylonites. The mineralogy is largely the same in the higher-strain rocks compared to the lowstrain rocks, except for zones of increased K-feldspar, chlo- rite, and epidote contents observed locally along some mylonite-ultramylonite transitions. There is a slight increase in phyllosilicate content, mostly muscovite, in the mylonites compared to the protomylonites, but such increase is not seen in the ultramylonites compared to the mylonites [57]. In the mylonites, the feldspar porphyroclasts are smaller $(<1 \mathrm{~mm})$ and rounder compared to the protomylonites (Figures 6(a)-6(c)); however, the other microstructural observations still apply. The proportion of K-feldspar to plagioclase is higher than in the protomylonites, as is the proportion of neoblasts to porphyroclasts. The quartz ribbons are thinner, compared to the protomylonites, and are only a few grains wide at their thickest in the mylonites (Figures 6(a)-6(c)). Whereas the quartz ribbons of the mylonites display a CPO, most of the quartz in the ultramylonites is dispersed in the fine-grained matrix (Figures 6(d)-6(f)) and lacks a CPO [57]. The phyllosilicates are fine grained $(<30 \mu \mathrm{m})$ and dispersed within the matrix. In the mylonites, the phyllosilicates are arranged into interconnected networks, 


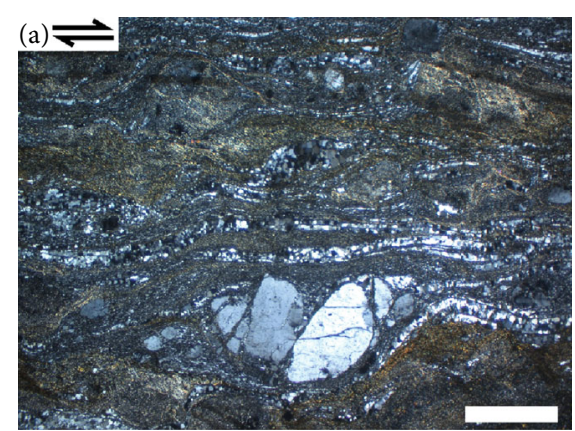

(a)

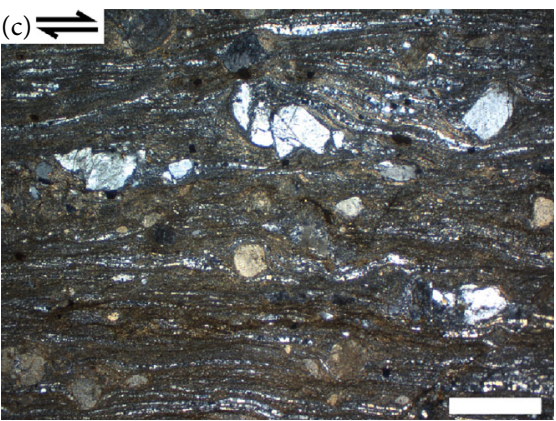

(c)

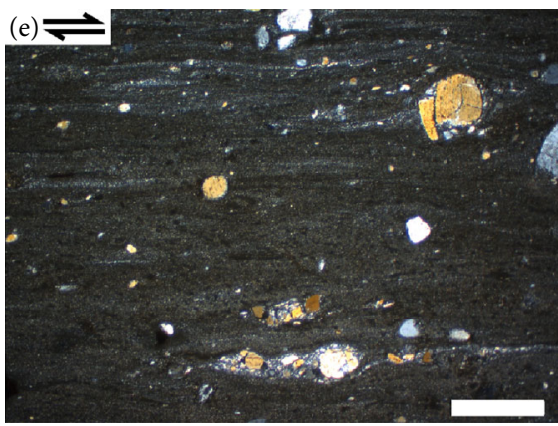

(e)

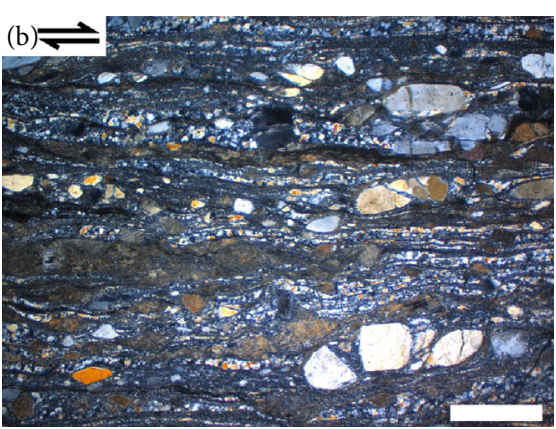

(b)

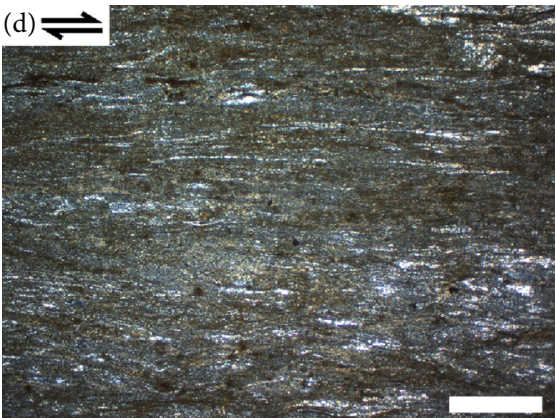

(d)

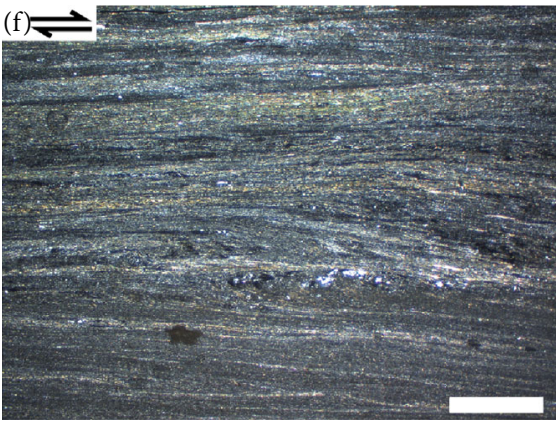

(f)

FIGURE 6: Photomicrographs of high-strain rocks from the KMZ. (a-c) are representative mylonites with feldspar porphyroclasts containing tensile and shear fractures, quartz ribbons, and a fine-grained matrix. (d-f) are representative ultramylonites, dominated by fine-grained mixtures of all constituent phases of the rock, with a few relict feldspar porphyroclasts. (a) Sample 31, Tsirub Gneiss from area C. (b) Sample 25, biotite gneiss from area D. (c) Sample 34, leucogranite from area C. (d) Sample 32, Tsirub Gneiss from area C. (e) Sample 10, biotite gneiss from area A. (f) Sample 42, leucogranite from area B. White bars $=1 \mathrm{~mm}$.

a few grains thick, with their basal plane aligned subparallel to foliation and long axis subparallel to the lineation direction (Figure 7(a)). These networks of interconnected phyllosilicates are not present in the ultramylonites, where although similarly present and oriented, they are not connected (Figure $7(\mathrm{~b})$ ). The ultramylonites consist nearly completely of a finegrained $(<20 \mu \mathrm{m})$, distributed mixture of all constituent phases of the rock, with fine grains of mostly feldspars and quartz $(<5 \mu \mathrm{m})$ present in many triple junctions [57]. Kfeldspar porphyroclasts, $<1 \mathrm{~mm}$ in size and well rounded, are nonetheless still present in a few ultramylonites (Figure 6).

\section{Geochemical Methods}

In the KMZ, areas enriched in K-feldspar or chlorite and/or epidote are identified at the outcrop scale, predominantly adja- cent to ultramylonite cores of local shear zones (Figures 2, 3, and 4). Furthermore, replacement reactions, including plagioclase breakdown and growth of muscovite, feldspars, and quartz, can be inferred from thin sections (Figures 5 and 6).

The occurrence of these replacement phases is still localised to the mylonites, and increase in abundance from the protomylonites to the mylonites and further to the ultramylonites. These reactions require an increase in water content from proto- to ultramylonites, and may have also involved a component of mass transfer. A fluid is thus needed, the source and effect of which will be investigated further with the help of geochemical methods.

The rock samples collected are therefore also used to measure oxygen isotope ratios as well as bulk whole rock major-, minor-, and trace-element concentrations using $\mathrm{X}$-ray fluorescence (XRF). Although quartz veins are very 


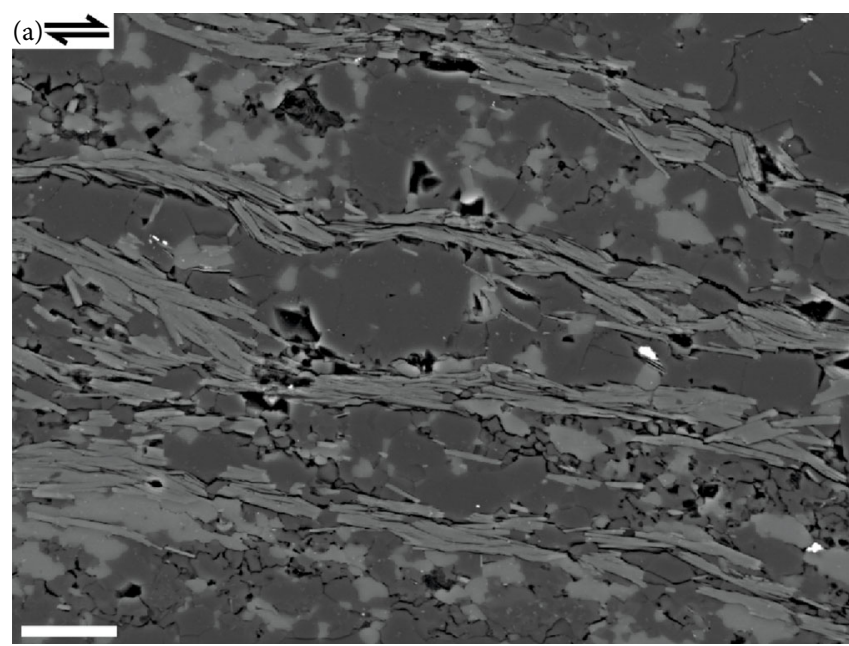

(a)

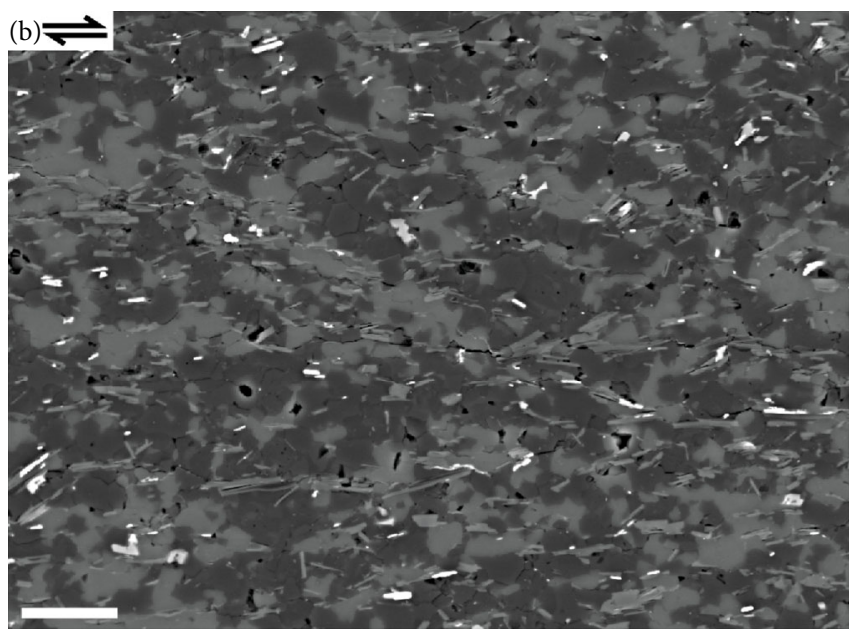

(b)

FIGURE 7: Scanning electron microscope backscatter electron images of (a) layers of interconnected phyllosilicate networks in a mylonite and (b) a representative ultramylonite depicting a fine-grained mixture, with a random distribution of all constituent phases of the rock. Quartz and albite are dark gray, K-feldspar is light gray, and phyllosilicates are light gray and lamellar shaped. White bars $=20 \mu \mathrm{m}$.

rare in the KMZ, where synkinematic quartz veins were found, they were sampled for isotopic analysis from within and outside the four areas described above. The quartz veins chosen were parallel to foliation, ductilely deformed, slightly boudinaged, and/or exhibited a similar mineral lineation to the surrounding rocks, and therefore interpreted as synkinematic (Figure 4(e)). All samples were crushed with a Sturtevant laboratory jaw-crusher and, apart from the quartz samples, further powdered with a tungsten carbide mill. The geochemical analyses on the powders and quartz chips were conducted at Cape Town University.

5.1. Oxygen Isotopes. O-isotope data are presented in delta notation as given by

$$
\delta=\left(\frac{R_{\mathrm{x}}-R_{\mathrm{std}}}{R_{\mathrm{std}}}\right) \times 1000
$$

where $R$ is the ratio of ${ }^{18} \mathrm{O} /{ }^{16} \mathrm{O}, \mathrm{x}$ represents the sample, and std stands for standard.

The oxygen isotope analyses of quartz and whole rock samples were performed using both laser and conventional fluorination. The laser fluorination follows the method of Harris and Vogeli [58], where 2-3 mg clean quartz chips were reacted with $\mathrm{BrF}_{5}$ and collected as $\mathrm{O}_{2}$. For the conventional fluorination, analyses were made using externally heated $\mathrm{Ni}$ bombs, employing $\mathrm{ClF}_{3}$ as a reagent at $550^{\circ} \mathrm{C}$, and converting the liberated $\mathrm{O}_{2}$ to $\mathrm{CO}_{2}$. Raw data were converted to $\delta$ -notation relative to standard mean ocean water (SMOW) based on internal garnet (MON GT; $\delta^{18} \mathrm{O}=5.38 \%$ ) and quartz (MQ; $\delta^{18} \mathrm{O}=10.1 \%$ ) standards, for data obtained by the laser and conventional fluorination methods, respectively. Duplicates of the standards were run with each batch to monitor analytical precision, with the long-term variability suggesting $2 \sigma$ errors of $0.15 \%$ o (MON GT) and $0.16 \%$ (MQ).
5.2. XRF. Bulk rock major- and trace-element compositions were measured on a Panalytical Axios wavelength-dispersive XRF spectrometer housed in the Department of Geological Sciences at the University of Cape Town. Samples were heated to $110^{\circ} \mathrm{C}$ overnight, for at least 8 hours, to dry. The powders were weighed before and after this drying process to record loss of absorbed water $\left(\mathrm{H}_{2} \mathrm{O}-\right)$. After this, the samples were heated in a ceramic crucible and held at a temperature of $850^{\circ} \mathrm{C}$ for at least 4 hours, before cooling and weighing again to record Loss On Ignition (LOI). The samples were subsequently fused with a lithium borate flux to produce fused discs, on which major element compositions were measured, and pressed powder briquettes, from which trace-element data were recorded.

\section{Geochemical Results with Additional Calculations}

The chemical compositions of the Tsirub Gneiss, biotite gneiss, and leucogranite indicate that they are granitic in composition (Table 1). Even though the ranges above exclude samples enriched in chlorite, epidote, or K-feldspar, there are still significant variations in elemental concentrations. These variations are likely found in variably deformed samples. To test this, and to better visualise these variations, the graphical isocon method presented by Grant [59] is used. Tables of the compositions of all rocks are provided in the supplements (Table S2).

6.1. Isocon Method. The isocon diagram [59] allows for a qualitative visualisation of changes in element concentrations and mass changes between two samples. With the premise that fluid flow is channelised in shear zones, it was used separately for all transects to compare the whole rock XRF data for each sample within and around the high-strain zones against the least deformed samples of the same protolith. Once the chosen samples are plotted against each other in a diagram, a line is plotted from the origin through a chosen 
TABLE 1: Compositional ranges for the biotite gneiss, Tsirub Gneiss, and the leucogranite.

\begin{tabular}{lccc}
\hline & Biotite gneiss & Tsirub Gneiss & Leucogranite \\
\hline $\mathrm{SiO}_{2}$ & $61.98-71.50$ & $66.36-74.38$ & $70.52-79.80$ \\
$\mathrm{TiO}_{2}$ & $0.13-0.89$ & $0.13-0.20$ & $0.13-0.30$ \\
$\mathrm{Al}_{2} \mathrm{O}_{3}$ & $13.80-15-.22$ & $13.53-15.03$ & $9.12-14.18$ \\
$\mathrm{Fe}_{2} \mathrm{O}_{3}$ & $1.73-7.79$ & $1.31-4.15$ & $1.22-2.56$ \\
$\mathrm{MnO}$ & $0.01-0.12$ & $0.02-0.07$ & $0.02-0.03$ \\
$\mathrm{MgO}$ & $0.34-3.18$ & $0.25-1.11$ & $0.13-0.45$ \\
$\mathrm{CaO}$ & $0.14-4.52$ & $0.45-1.51$ & $0.10-0.50$ \\
$\mathrm{Na}_{2} \mathrm{O}$ & $2.44-4.66$ & $2.58-3.37$ & $0.25-3.47$ \\
$\mathrm{~K}_{2} \mathrm{O}$ & $3.14-6.51$ & $4.29-6.19$ & $4.61-6.79$ \\
$\mathrm{P}_{2} \mathrm{O}_{5}$ & $0.07-0.22$ & $0.07-0.28$ & $0.04-0.18$ \\
$\mathrm{SO}_{3}$ & $0.00-0.01$ & $0.00-0.01$ & $0.00-0.01$ \\
$\mathrm{Cr}_{2} \mathrm{O}_{3}$ & $0.00-0.03$ & $0.00-0.02$ & 0.00 \\
$\mathrm{NiO}$ & 0.01 & $0.01-0.02$ & 0.01 \\
$\mathrm{H}_{2} \mathrm{O}^{-}$ & $0.07-0.19$ & $0.18-0.31$ & $0.06-0.17$ \\
$\mathrm{LOI}^{\mathrm{Total}}$ & $0.73-1.38$ & $0.62-1.79$ & $0.66-1.40$ \\
\hline
\end{tabular}

immobile element, the slope of which gives the inferred mass change of the deformed sample compared to the protolith. Titanium is typically immobile (e.g., $[51,60]$ ), but Ti contents are too low to be representative of element mobility in several of our rocks. We therefore assumed the immobility of aluminium, as it has previously been shown to be immobile during deformation of granitoids at similar conditions [61-63]. We also note that all samples have a mean aluminium saturation index (as defined by Zen [64]) of $1.12( \pm 0.11)$, indicating aluminium saturation and no trends of aluminium mobility between high- and low-strain rocks (Table S1). A 1:1 relationship means no mass change; if the gradient is lower than that, the deformed sample has experienced mass gain compared to the protolith, and conversely a mass loss if the gradient is higher. The elements plotting above the 1:1 line have increased in weight $\%$ in the deformed sample compared to the protolith, whereas the ones plotting below the line have decreased. Scaling factors are used to disperse the elements over the graph for easier qualitative evaluation of relative changes.

For quantitative results comparing all our deformed samples to their protoliths, calculations were made following Spruzeniece and Piazolo's [52] adaptation of the original equations of Gresens [65]. To estimate the changes in concentration of major, minor, and trace elements between the protolith and the deformed sample, equation (2) was used, where $\Delta M$ is the mass change in percent and $C$ is concentration. The total mass change (in \%) between the two analysed samples can be estimated using equation (3), where $S$ is the slope of the isocon $\left(S=\left(C_{\text {immobile }}^{\text {deformed }} / C_{\text {immobile }}^{\text {protolith }}\right)\right)$.

$$
\Delta M_{\text {mobile }}=\left(\left(\frac{C_{\text {immobile }}^{\text {protolith }}}{C_{\text {immobile }}^{\text {deformed }}}\right)\left(\frac{C_{\text {mobile }}^{\text {deformed }}}{C_{\text {mobile }}^{\text {protolith }}}\right)-1\right) \times 100,
$$

$$
\Delta M_{\text {total }}\left(\left(\frac{1}{S}\right)-1\right) \times 100 .
$$

6.2. Element Mobility with Inferred Mass Changes (\%). Here, we compare a selection of eight samples of highly strained rocks from all four areas to their wall rocks, with the aid of isocon diagrams (Figure 8), to assess their chemical changes. We also evaluate one pink and one green sample, representative of the K-feldspar and epidote/chlorite-enriched rocks in the KMZ, respectively. Tables of changes in element concentration and mass for all rocks can be found in the supplements (Table S3).

6.2.1. Area $A$. The two ultramylonites (CKMZ 4 and 10; Figure 2) on the edges of the shear zone in area A were chosen for this evaluation, as their protoliths (CKMZ 2 and 12; Figure 2) are more unambiguous compared to the central, third, ultramylonite. On the biotite gneiss side (Figure 8), the element mass changes vary from $-88 \%(\mathrm{MgO})$ to $+120 \%$ $\left(\mathrm{K}_{2} \mathrm{O}\right)$.

Relatively big losses (51-88\%) are also seen in $\mathrm{TiO}_{2}$, $\mathrm{Fe}_{2} \mathrm{O}_{3}, \mathrm{MnO}$, and $\mathrm{CaO}$. Apart from $\mathrm{K}_{2} \mathrm{O}$, the only other gain was experienced by $\mathrm{SiO}_{2}(21 \%)$. The changes are much smaller on the Tsirub Gneiss side (Figure $\mathrm{S} 1$ ), with a range from $-58 \%(\mathrm{CaO})$ to $+8 \%\left(\mathrm{Na}_{2} \mathrm{O}\right)$. The ultramylonites experienced a relative loss of most elements, apart from negligible gains in $\mathrm{SiO}_{2}$ and $\mathrm{TiO}_{2}$.

6.2.2. Area $B$. The rock with the least amount of strain on the biotite gneiss side in area B, a protomylonite (CKMZ 39), exhibited anomalous aluminium concentrations. For this reason, the wall rock from area $\mathrm{A}$, an along-strike equivalent (CKMZ 12), was used in relative mass loss calculations for the biotite gneiss mylonites in area B (Figure 2). The biotite gneiss ultramylonite (CKMZ 41; Figure 2) has experienced gains of $\mathrm{SiO}_{2}(24 \%), \mathrm{Na}_{2} \mathrm{O}$ (17\%), and $\mathrm{K}_{2} \mathrm{O} \quad(75 \%$; Figure $\mathrm{S} 1$ ). The losses of all other elements range from $21 \%$ in $\mathrm{NiO}$ to $97 \%$ in $\mathrm{CaO}$. On the leucogranite side (Figure 8), the ultramylonite (CKMZ 42; Figure 2) has experienced gains of $789 \%$ in $\mathrm{Na}_{2} \mathrm{O}$, but a loss of $<84 \%$ of other major elements.

6.2.3. Area $C$. As the local high-strain zone in area $C$ is relatively narrow, only 5 samples were collected, one of which was an ultramylonite (CKMZ 33; Figure 2). To be more confident in that the changes outlined here are relative to the correct protolith, we look at the mylonites on either side of the central ultramylonite. On the leucogranite side (Figure S1), notable changes occurred in $\mathrm{MgO}(+173 \%)$ and $\mathrm{CaO}(+174 \%)$ with the rest having experienced changes of only $\pm<18 \%$. The mylonite on the Tsirub Gneiss side exhibited lower changes $(<87 \%)$, with gains of $\mathrm{SiO}_{2}, \mathrm{Na}_{2} \mathrm{O}$, and $\mathrm{K}_{2} \mathrm{O}$, and losses of $\mathrm{TiO}_{2}, \mathrm{Fe}_{2} \mathrm{O}_{3}, \mathrm{MnO}, \mathrm{MgO}, \mathrm{CaO}$, $\mathrm{P}_{2} \mathrm{O}_{5}$, and $\mathrm{NiO}$ (Figure 8).

6.2.4. Area $D$. In area $D$, all samples have the same protolith (Figure 3). Calculations where nevertheless still made using the least deformed samples, migmatitic biotite gneiss (CKMZ 18 and 28), from either end of the transect. Here, we look at one ultramylonite sample (CKMZ 25) calculated against the 

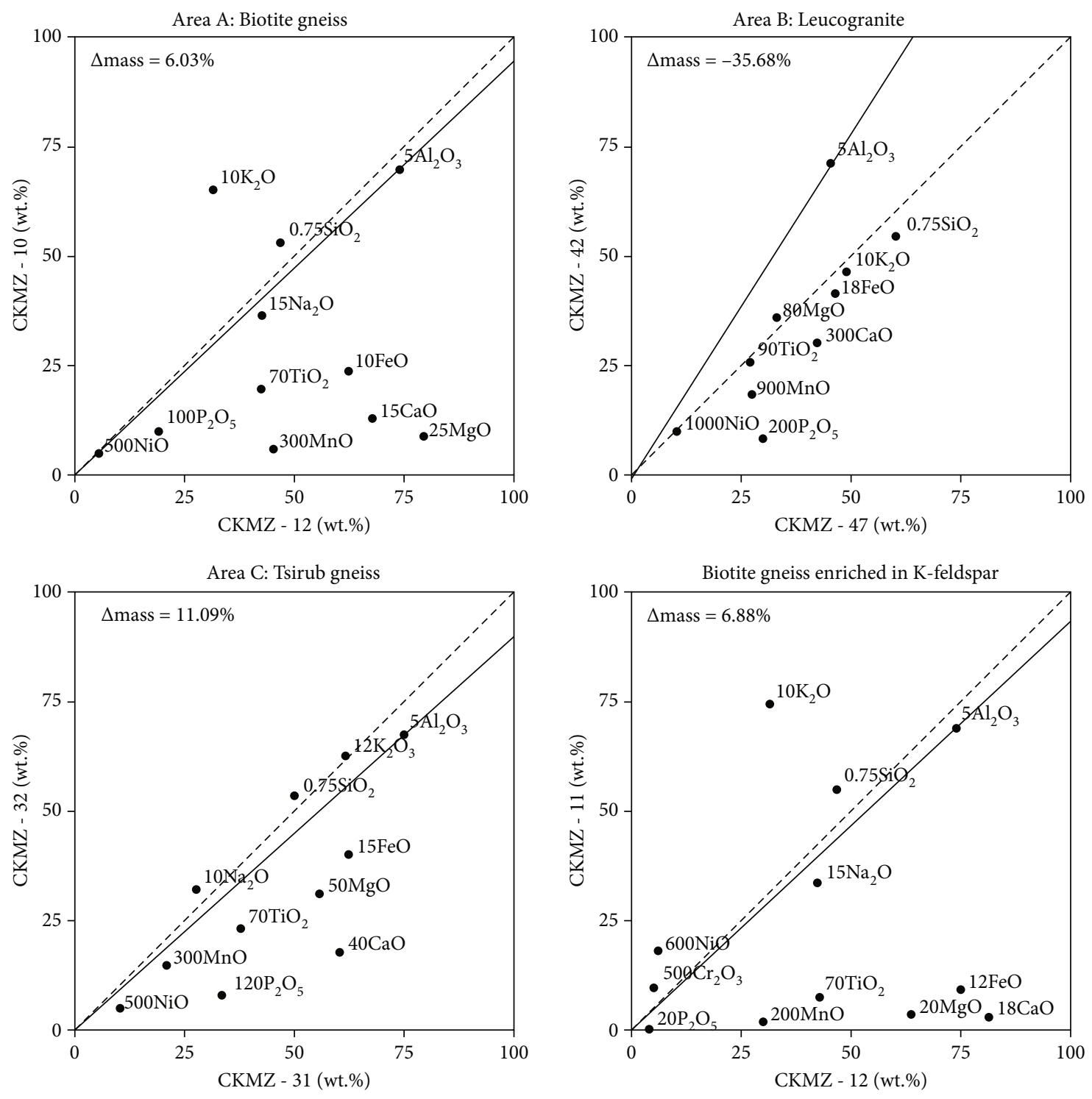

Figure 8: Part of the isocons described in the text showing changes in element concentrations and mass changes between two samples. Rock descriptions can be found in Table S1, and the remaining isocons can be found in Figure S1.

protolith to the south, due to its closer proximity, and a protomylonite (CKMZ 22) just north of the zone enriched in chlorite and epidote, against the biotite gneiss north of the local high-strain zone. The ultramylonite experienced relatively minor changes $(<47 \%)$, with gains of $\mathrm{SiO}_{2}, \mathrm{Na}_{2} \mathrm{O}$, $\mathrm{K}_{2} \mathrm{O}$, and $\mathrm{NiO}$ as well as losses of $\mathrm{TiO}_{2}, \mathrm{Fe}_{2} \mathrm{O}_{3}, \mathrm{MnO}, \mathrm{MgO}$, $\mathrm{CaO}$, and $\mathrm{P}_{2} \mathrm{O}_{5}$ (Figure $\mathrm{S} 1$ ). Similarly, the protomylonite underwent small relative gains $(<10 \%)$ of $\mathrm{SiO}_{2}, \mathrm{Na}_{2} \mathrm{O}$, and $\mathrm{K}_{2} \mathrm{O}$, but experienced moderately larger losses $(<90 \%)$ of the other major elements (Figure S1).

6.2.5. Chlorite/Epidote- (Green) and K-Feldspar- (Pink) Enriched Samples. One green sample (area D; CKMZ 23; Figure 3) and one pink sample (area A; CKMZ 11; Figure 2) were chosen for analysis. The green sample had experienced gains $(<32 \%)$ of $\mathrm{TiO}_{2}, \mathrm{Fe}_{2} \mathrm{O}_{3}, \mathrm{MgO}, \mathrm{CaO}, \mathrm{Na}_{2} \mathrm{O}$, and $\mathrm{P}_{2} \mathrm{O}_{5}$, as well as losses $(<52 \%)$ of $\mathrm{SiO}_{2}, \mathrm{MnO}$, and $\mathrm{K}_{2} \mathrm{O}$ (Figure S1).
The pink sample on the other hand experienced notable gains of $\mathrm{K}_{2} \mathrm{O}(154 \%)$ and moderately high losses (80-96\%) of $\mathrm{TiO}_{2}, \mathrm{Fe}_{2} \mathrm{O}_{3}, \mathrm{MnO}, \mathrm{MgO}, \mathrm{CaO}$, and $\mathrm{P}_{2} \mathrm{O}_{5}$ (Figure 8(j)).

6.2.6. Overall Trend. Some of the scatter may be explained by sample heterogeneity and/or analytical error; however, overall trends still emerge. The most obvious patterns across the $\mathrm{KMZ}$ is the loss of $\mathrm{Fe}_{2} \mathrm{O}_{3}, \mathrm{MgO}$, and $\mathrm{CaO}$ and the gain of $\mathrm{SiO}_{2}, \mathrm{~K}_{2} \mathrm{O}$, and $\mathrm{Na}_{2} \mathrm{O}$ in ultramylonites relative to their protoliths (Table 2). This trend is especially consistent in high-strain rocks with biotite gneiss or Tsirub Gneiss as wall rock. The two samples compared against the leucogranite do not only stray from this trend, but also have the highest measured variations in major element concentrations across the entire KMZ.

6.3. Total Mass Change. In the previous section, we discussed chemical changes between selected protolith-mylonite pairs. 
TABLE 2: The overall trend of changes in element concentrations in selected shear zone rocks relative to their protoliths, across the KMZ, is loss of $\mathrm{Fe}_{2} \mathrm{O}_{3}, \mathrm{MgO}$, and $\mathrm{CaO}$ and gain of $\mathrm{SiO}_{2}, \mathrm{~K}_{2} \mathrm{O}$, and $\mathrm{Na}_{2} \mathrm{O}$.

\begin{tabular}{lcccccccccc}
\hline Area & $\mathrm{A}$ & $\mathrm{A}$ & $\mathrm{B}$ & $\mathrm{B}$ & $\mathrm{C}$ & $\mathrm{C}$ & $\mathrm{D}$ & $\mathrm{D}$ & $\mathrm{A}(\mathrm{x})$ & $\mathrm{D}(\mathrm{x})$ \\
\hline Sample & 4 & 10 & 41 & 42 & 32 & 34 & 22 & 25 & 11 & 23 \\
$\mathrm{Rock}$ type & $\mathrm{TG}$ & $\mathrm{BG}$ & $\mathrm{BG}$ & $\mathrm{LG}$ & $\mathrm{TG}$ & $\mathrm{LG}$ & $\mathrm{BG}$ & $\mathrm{BG}$ & $\mathrm{BG}$ & $\mathrm{BG}$ \\
$\mathrm{SiO}_{2}$ & $\mathbf{1 . 3}$ & $\mathbf{2 1 . 0}$ & $\mathbf{2 4 . 0}$ & -41.8 & $\mathbf{1 9 . 9}$ & -9.4 & $\mathbf{1 0 . 3}$ & $\mathbf{1 1 . 8}$ & $\mathbf{2 6 . 5}$ & -6.8 \\
$\mathrm{TiO}_{2}$ & $\mathbf{0 . 2}$ & -51.0 & -59.2 & -39.7 & -29.1 & -5.3 & -35.5 & -35.2 & -80.2 & $\mathbf{7 . 8}$ \\
$\mathrm{Al}_{2} \mathrm{O}_{3}$ & & & & & & & & \\
$\mathrm{Fe}_{2} \mathrm{O}_{3}$ & -6.7 & -59.4 & -70.6 & -42.9 & -27.8 & -18.3 & -28.5 & -17.5 & -86.7 \\
$\mathrm{MnO}$ & -34.5 & -84.4 & -92.3 & -70.6 & -29.2 & $\mathbf{5 . 8}$ & -23.5 & -22.2 & -92.8 \\
$\mathrm{MgO}$ & -13.5 & -88.3 & -88.6 & -28.7 & -37.0 & $\mathbf{1 7 3 . 3}$ & -21.0 & -44.0 & -93.5 \\
$\mathrm{CaO}$ & -57.6 & -80.0 & -96.8 & -54.7 & -67.0 & $\mathbf{1 7 4 . 0}$ & -19.3 & -46.9 & -96.1 \\
$\mathrm{Na}{ }_{2} \mathrm{O}$ & $\mathbf{8 . 1}$ & -7.9 & $\mathbf{1 6 . 5}$ & $\mathbf{7 8 8 . 8}$ & $\mathbf{3 0 . 6}$ & $\mathbf{8 . 7}$ & $\mathbf{0 . 2}$ & $\mathbf{9 . 3}$ & -15.0 \\
$\mathrm{~K}_{2} \mathrm{O}$ & -11.8 & $\mathbf{1 1 9 . 6}$ & $\mathbf{7 4 . 6}$ & -39.5 & $\mathbf{1 3 . 3}$ & -16.6 & $\mathbf{0 . 1}$ & $\mathbf{3 7 . 1}$ & $\mathbf{1 0 . 3}$ \\
$\mathrm{P}_{2} \mathrm{O}_{5}$ & -56.9 & -42.4 & -63.4 & -82.2 & -72.2 & -17.2 & -34.7 & -27.7 & -82.4 \\
$\mathrm{NiO}$ & -46.3 & -7.1 & -21.0 & -35.3 & -41.3 & -6.0 & -30.6 & $\mathbf{6 . 9}$ & $\mathbf{6 . 9}$ \\
\hline
\end{tabular}

TG=Tsirub Gneiss; $\mathrm{BG}=$ biotite gneiss; $\mathrm{LG}=$ leucogranite; $(\mathrm{x})=$ enriched in K-feldspar/epidote/chlorite. Loss=italics. Gain=bold.

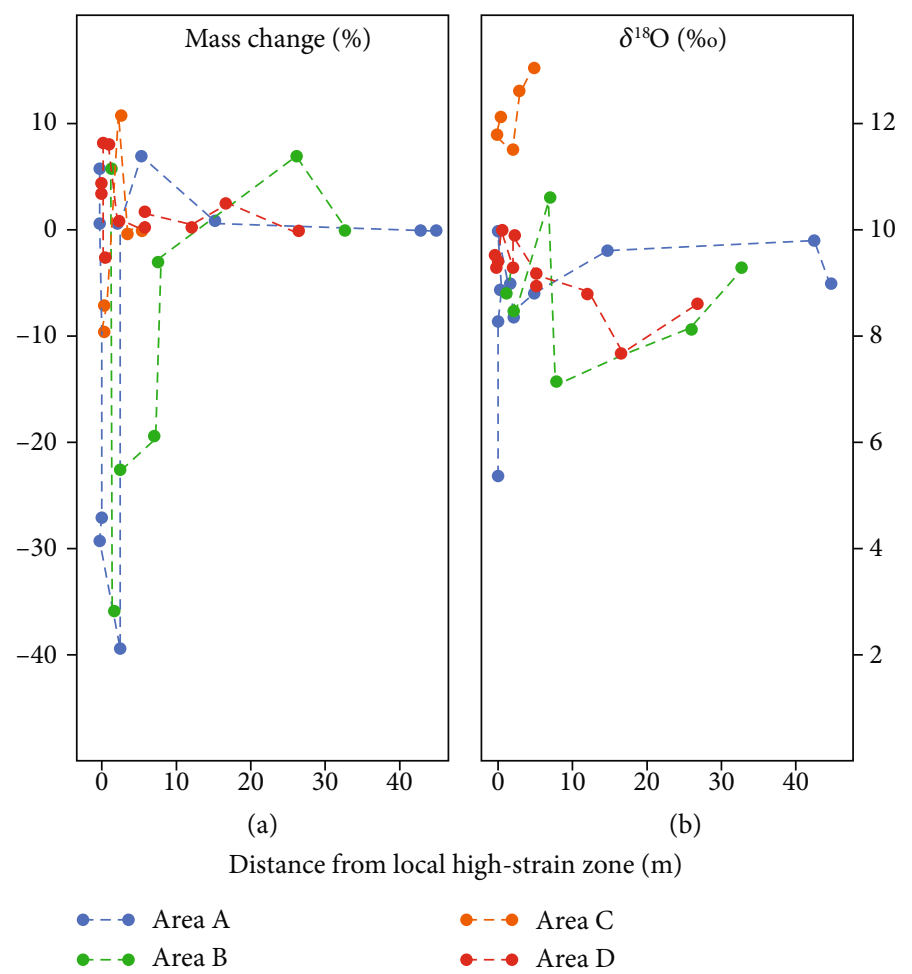

FIGURE 9: Mass changes (a) and $\delta^{18} \mathrm{O}$ values (b) against distance from local high-strain zones. The largest mass change occurs closer to the high-strain zones. Proximity to the local high-strain zones does not seem to affect the $\delta^{18} \mathrm{O}$ value.

We now consider mass changes across all the transects using all samples. Whereas the changes in some of the individual elements are significant, the same cannot be said about the relatively low range of mass changes in the KMZ $(-39 \%$ to $+11 \%$ ), with an almost negligible average of $-4.5 \%$ (Figure 9, Table S3). Most mass changes greater than $\pm 10 \%$ are found within $5 \mathrm{~m}$ of the local high-strain zone cores. The majority of the samples $>5 \mathrm{~m}$ away from the high-strain zones show only minor $(<5 \%)$ mass changes, with a few exceptions of both losses and gains. This correlates with the observations of a higher proportion of retrograde minerals adjacent to the cores of the local high-strain zones.

In area $\mathrm{A}$, the mass changes are $<7 \%$ except for within and immediately adjacent to the domain of granitic composition and texture, where some of the biggest losses in the KMZ are found (Figure 10). The highest mass loss (39\%) was calculated for a sample obtained from an area of the granitic domain with a brittle overprint. Similar mass losses are found in area B (Figure 10), where all three mylonitized samples of the leucogranite show mass losses in excess of $20 \%$. Because 

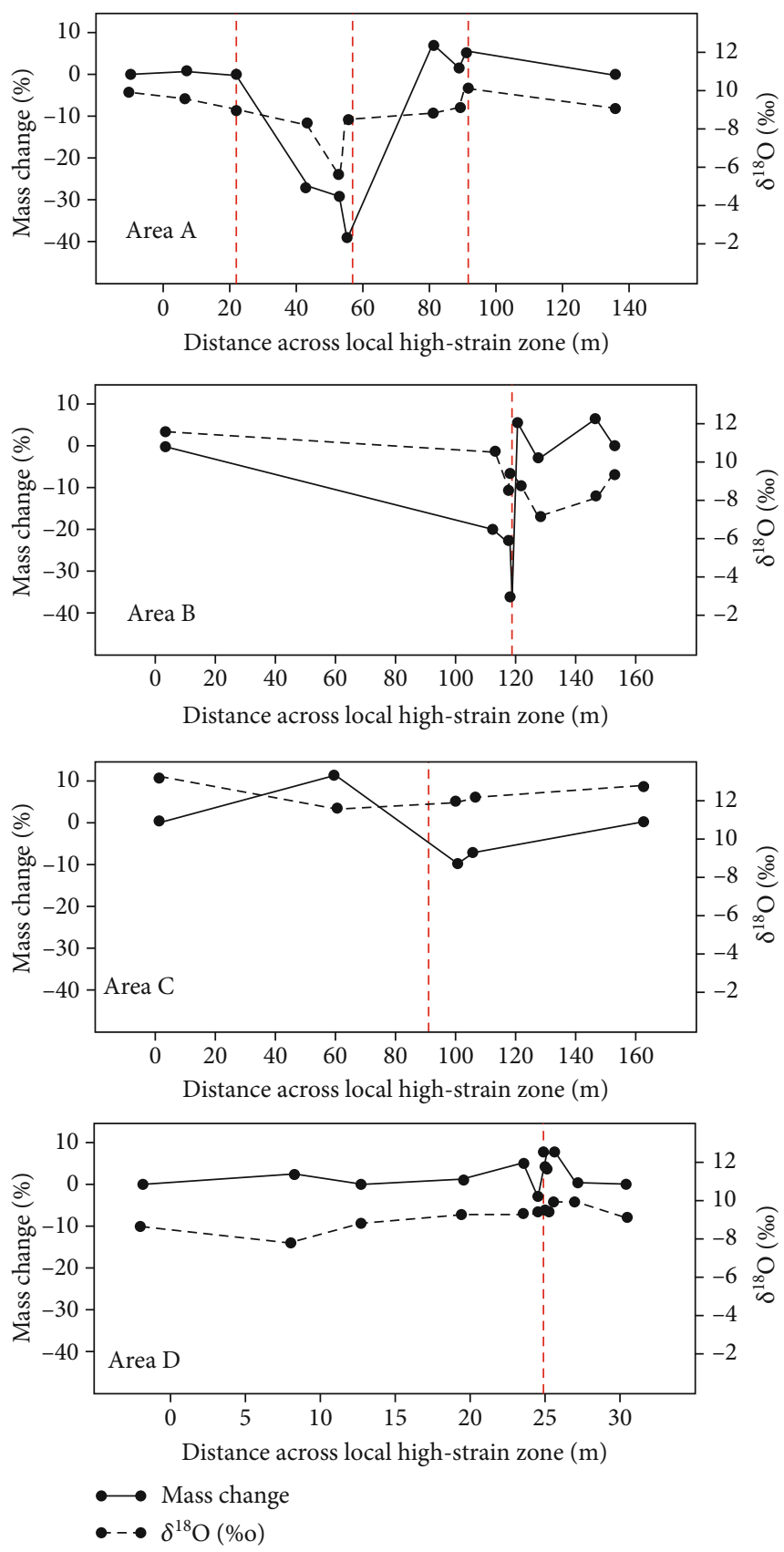

Figure 10: Mass changes and $\delta^{18} \mathrm{O}$ values against distance $(0=$ northern end of transect) across the local high-strain zones in areas A-D. The dashed red lines represent the cores of local high-strain zones.

of anomalous XRF results for the biotite gneiss wall rock in area $\mathrm{B}$, calculations for the deformed samples were made against the wall rock in area A. The results showed no significant mass changes, much like the biotite gneiss side in area A. In areas $\mathrm{C}$ and $\mathrm{D}$, the mass changes are within $\pm 10 \%$, with the greatest changes close to the ultramylonites (Figures 10). Even though the chlorite/epidote and K-feldspar-enriched samples display significant changes in concentration of individual elements across the KMZ, their overall mass changes do not differ by more than $\sim 10 \%$ compared to the adjacent rock samples (Table S3).

6.4. Oxygen Isotope Compositions. HDGEO_3023268The average mass change of $-4.5 \%$ between deformed rocks and their protoliths in the KMZ is negligible, and even the maximum individual sample mass change of $-39 \%$ is an order of magnitude lower than the volume gain of $240 \%$ reported by Spruzeniece and Piazolo [52] for rocks from a brittleductile shear zone belonging to the Wyangala shear zone system, within the Wyangala batholith in the Eastern Lachlan Fold belt, Australia, and half of the volume loss (-60\%) reported by O'Hara [51] for granitic gneisses of the Blue Ridge province, deformed at similar conditions to the KMZ, along the Rector Branch thrust fault in the southern Appalachians. Nonetheless, mass changes are indicated by the isocon diagrams and variations in the concentrations of elements for individual rock samples are in places substantial (Table 2; Figures 9 and 10). There is therefore a need for a synkinematic, localised, fluid presence, the source of which can be constrained using oxygen isotopic compositions.

We measured both quartz vein and whole rock $\delta^{18} \mathrm{O}$ values. Quartz veins are direct precipitates from fluids, and the $\delta^{18} \mathrm{O}$ value of the fluid at the time of precipitation can be estimated using the inferred temperature of precipitation. The whole rock data on the other hand allows us to assess changes in $\delta^{18} \mathrm{O}$ value between samples from within the shear zones and their wall rocks. Both the quartz and the whole rock $\delta^{18} \mathrm{O}$ depend on the nature of the fluid-rock interaction, with initial fluid $\delta^{18} \mathrm{O}$ value, the fluid/rock ratio, and temperature controlling the final $\delta^{18} \mathrm{O}$ value. The $\delta^{18} \mathrm{O}$ values of fluids from different sources are highly variable, in simple terms meteoric water has values $<0 \%$, whereas values from $\sim 5$ to $10 \%$ are typical of either magmatic or metamorphic fluids, and high values ( $>10 \%$ ) are typical of metamorphic fluids where the protolith has a high authigenic mineral component (metapelites and metacarbonates; Figure 11).

6.4.1. Quartz Vein $\delta^{18} O$. The quartz veins have a range in $\delta^{18} \mathrm{O}$ values from -1.2 to $11.6 \%$ with a mean value of $8.0 \pm 4.1 \%$ o $(n=8$; Figure 12; Table S1). The large standard deviation is caused by six out of the eight samples ranging between 8 and $12 \%$, with only two outliers with the low values of -1.2 and $4.2 \%$. The quartz vein with a $\delta^{18} \mathrm{O}$ value of $4.2 \%$ is from the mylonite-hosted veins in area B.

The negative quartz $\delta^{18} \mathrm{O}$ value is from the middle of area $\mathrm{A}$, on the "granitic" domain side of the boundary to the central ultramylonite zone (Figure 2(b)). A second analysis of quartz chips from this vein was performed to validate the negative $\delta^{18} \mathrm{O}$ value, and a value of $-3.8 \%$ was obtained. The differing value is likely due to vein heterogeneity; however, it conforms to the previous low value. If we assume that the quartz vein with a negative $\delta^{18} \mathrm{O}$ value precipitated at the typical $T$ of KMZ mylonitic deformation, then this quartz formed from water with a $\delta^{18} \mathrm{O}$ value of $\sim-4 \%$, as the quartz-water fractionation at $450^{\circ} \mathrm{C}$ is $\sim 3 \%$ [66].

6.4.2. Whole Rock $\delta^{18} \mathrm{O}$. The whole rock samples have $\delta^{18} \mathrm{O}$ values which range from 5.4 to $13.1 \%$, with a mean of 


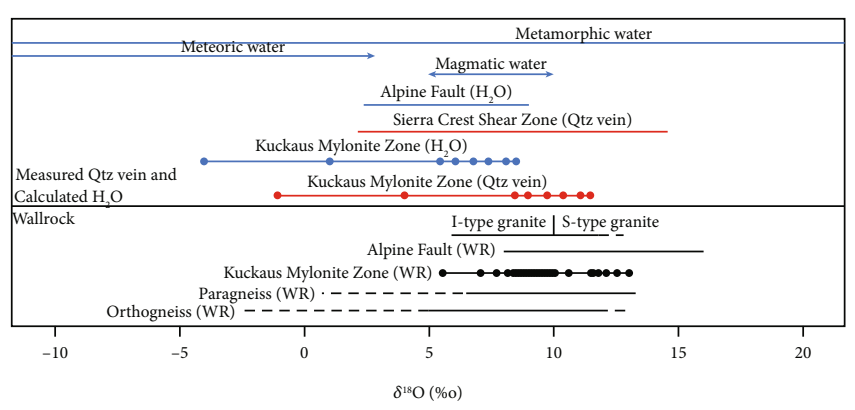

Figure 11: The ranges of $\delta^{18} \mathrm{O}$ values determined for samples from the KMZ. Whole rock values are in black, and the quartz veins are in red. Also plotted (in blue) are calculated $\mathrm{H}_{2} \mathrm{O}$ compositions for the quartz veins using the fractionation factor of Matsuhisa et al. [66]. Also shown are the ranges of meteoric, metamorphic, and magmatic waters, as well as typical I- and S-type granite and paraand orthogneiss whole rock values. The dashed line part of the para- and orthogneiss ranges are inferred to be affected by secondary processes. The Sierra Crest Shear Zone quartz vein [48] and the Alpine Fault whole rock and $\mathrm{H}_{2} \mathrm{O}$ [40] ranges are also shown for comparison. Table of references and $\delta^{18} \mathrm{O}$ values for para- and orthogneiss ranges are provided in supplements (Table S4).

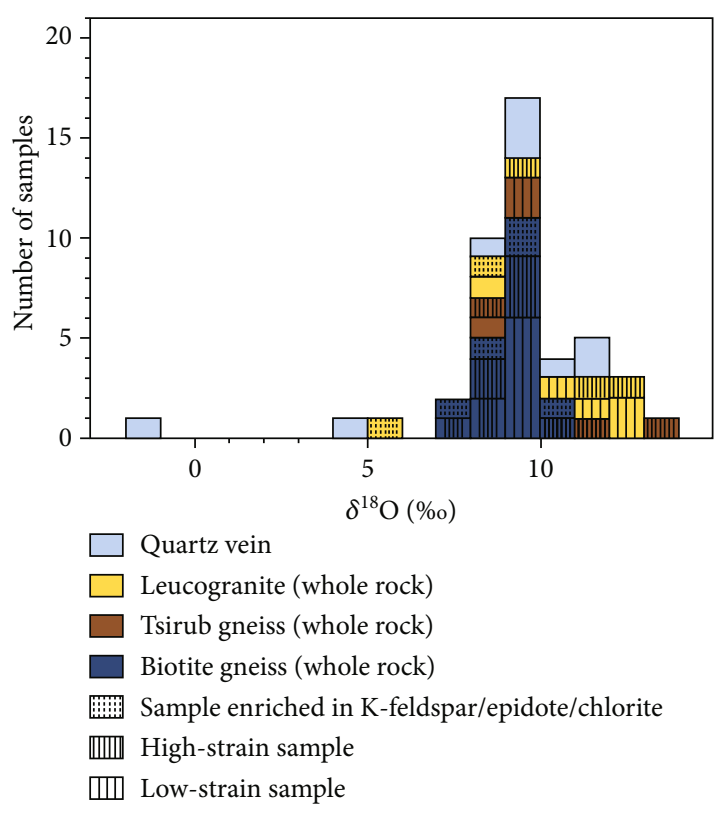

Figure 12: Oxygen $\delta^{18} \mathrm{O}$ spread for the KMZ.

$9.5 \pm 1.5 \%$ o $(n=35$; Figure 12 ; Table $\mathrm{S} 1)$. The two gneisses have mean $\delta^{18} \mathrm{O}$ values below and above this average, with the biotite gneiss predominantly hosting lower values (mean $=9.1 \pm 0.6 \%$ ) and Tsirub Gneiss conversely the higher $\left(\right.$ mean $=10.6 \pm 1.5 \%$ ). Whole rock $\delta^{18} \mathrm{O}$ values obtained from the leucogranite are spread over the whole range $\left(\right.$ mean $=10.6 \pm 1.6 \%$ ). The lowest whole rock $\delta^{18} \mathrm{O}$ value of $5.4 \%$ is from a granitic sample adjacent to the quartz vein in area $\mathrm{A}$ with the low quartz $\delta^{18} \mathrm{O}$ value of $-1.2 \%$ (Figure 2). Samples with increased abundance of chlorite and/or epidote or K-feldspar also have lower whole rock $\delta^{18} \mathrm{O}$ values, in general, than both high- and low-strain rocks, which have a similar distribution to each other. In both areas $\mathrm{C}$ and $\mathrm{D}$, the whole rock $\delta^{18} \mathrm{O}$ profiles across the sampled high-strain zones are flat (Figure 10), and apart from one leucogranite sample containing fractures, so is the profile for area $\mathrm{A}$ (Figure 10). In area $\mathrm{B}$, the whole rock $\delta^{18} \mathrm{O}$ values drop by $2 \%$ going in to the high-strain zone from both the low-strain leucogranite and biotite gneiss sides (Figure 10). Furthermore, the whole rock $\delta^{18} \mathrm{O}$ values do not show a clear correlation with mass changes across the KMZ (Figure 13).

\section{Discussion}

7.1. Fluid Sources. The synkinematic quartz veins, as well as the retrograde and replacement minerals, observed in the $\mathrm{KMZ}$ require influx of fluids during deformation. However, as the rocks in which the KMZ localised had experienced peak granulite facies metamorphic conditions, they were likely previously dehydrated [45]. The source/sources for the required fluids would therefore have been primarily external.

The synkinematic quartz veins are direct precipitates from at least one of these fluid sources, and can thereby give the $\delta^{18} \mathrm{O}$ of the fluid at the time of precipitation, assuming a temperature of precipitation. Excluding two low $\delta^{18} \mathrm{O}$ samples, the range in quartz vein $\delta^{18} \mathrm{O}$ values $(8.4-11.6 \%$ ) in the KMZ is within those expected for both metamorphic and magmatic fluid sources (Figure 11). On the other hand, as the quartz-water fractionation factor at $450^{\circ} \mathrm{C}$ is $\sim 3 \%$ [66], the two quartz veins with the lowest $\delta^{18} \mathrm{O}$ values of $-1.2 \%$ and $4.2 \%$ formed from water with $\delta^{18} \mathrm{O}$ values of $\sim-4 \%$ and $1 \%$, respectively. To retain these low values at depth when precipitating into veins, this initial $\delta^{18} \mathrm{O}$ of water would have had to have been $<-4 \%$. The fluid is therefore unambiguously of meteoric origin for this sample (Figure 11; [67]), unless the fluid originated from a very low $\delta^{18} \mathrm{O}$ rock predating KMZ activity [68], but no such material has been observed in the area. Whereas a few quartz veins were obtained from areas where brittle deformation has a ductile overprint, the sampled quartz veins were found parallel to foliation with some being slightly boudinaged and/or having a mylonitic mineral lineation consistent with the strike-slip kinematics of the KMZ (Figure 4(e)). Therefore, as the foliation formed during ductile deformation, at near-constant $T$ conditions of $\sim 450^{\circ} \mathrm{C}$ [45], so did the quartz veins. This implies that the KMZ, while actively deforming at midcrustal conditions, was at least locally and transiently connected to a fluid source at the surface.

Previous studies have proposed various models for how to get surface water down to and below the frictionalviscous transition, for example, inverted stress gradients in a compressional regime allowing dehydration fluids to flow up temperature [69], overthrusting of metamorphosed rocks over unmetamorphosed rocks [70], increased permeability at dilational jogs due to fracturing caused by hydraulic implosion [48], seismic pumping of fluids down a shallow decollement [71], and topographically driven fluid flow [40, 72]. Of these, however, only the Sierra Crest Shear Zone (SCSZ), California [48], is relevant in comparison to the KMZ. The others are reliant on their specific tectonic settings, all 


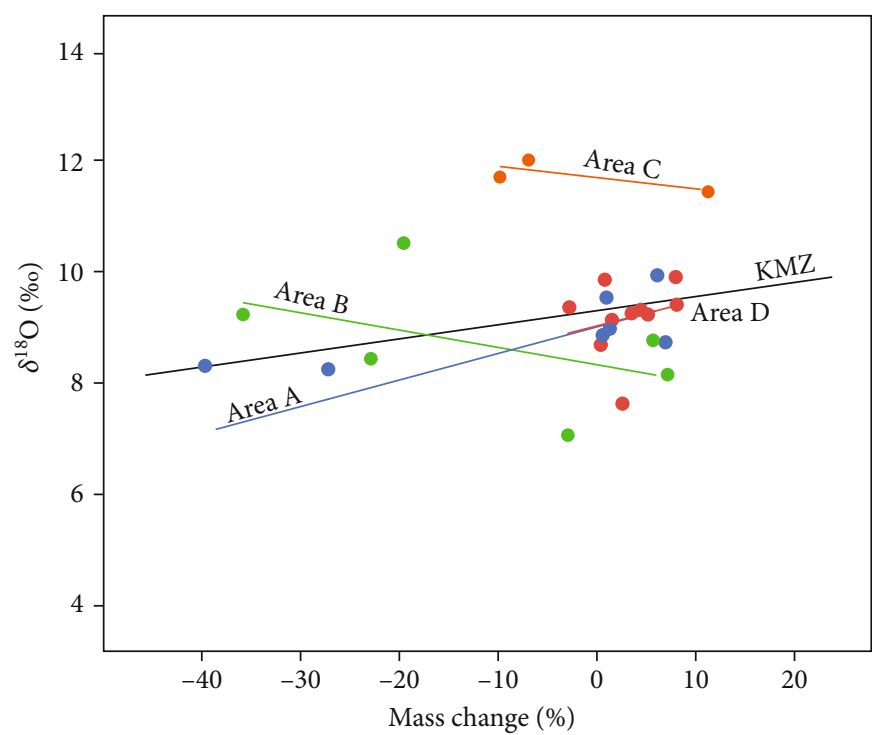

FIgURE 13: $\delta^{18} \mathrm{O}$ against mass change show weak correlation.

different to that of the strike-slip settings of both the SCSZ and the KMZ. In the SCSZ, dilational jogs allowed meteoric fluids to penetrate down to the brittle-ductile transition. The KMZ similarly shows signs of localised brittle deformation, albeit sparsely. In the KMZ, however, stress changes and associated damage related to earthquake propagation from the brittle crust above $[73,74]$ seem like a more likely option. Interestingly, recent experiments on calcite gouge have demonstrated how microscale cavitation can bring about a switch from dislocation and diffusion creep to dilatant deformation and lead to earthquake ruptures at conditions commonly associated with ductile flow [75], another potential mechanism for the KMZ if this mechanism can occur in quartzofeldspathic rocks. Furthermore, the dilatancy component inherent in creep cavitation may be sufficient to facilitate fluid flow in the mid- to lower crust $[14,16]$, without the need for earthquake ruptures.

The quartz vein $\delta^{18} \mathrm{O}$ values observed in the KMZ could simply be explained by fluids of the same O-isotope composition having variable degrees of exchange with rocks along the fluid pathway or by precipitation at different $T$. Whereas precipitation at different $T$ is unlikely given that there is no evidence for changing temperature during deformation [45], a variable degree of exchange remains viable. Veins precipitated from magmatic (granitic) fluids are reported to have a narrow range in $\delta^{18} \mathrm{O}$ values which covers the observed range of values from the KMZ (Figure 11). As the KMZ hosts synkinematic igneous intrusions, a fluid contribution from a magmatic (granitic) source seems likely. Metamorphic fluids, on the other hand, are harder to envisage as the gneisses would have been dehydrated at peak granulite facies conditions and subsequently lack hydrous minerals. Lateral fluid migration along strike is, however, still a viable option for metamorphic, as well as other, fluids, although no defined source is identified and viability of the transport distance is therefore not clear.

The whole rock $\delta^{18} \mathrm{O}$ values are consistent with the variable exchange at constant $T$ hypothesis. The only sample affected by a significant inferred exchange with meteoric water, because it has a $\delta^{18} \mathrm{O}$ value much lower than other rocks of the same protolith, is a leucogranite whole rock sample $\left(\delta^{18} \mathrm{O}=5.4 \%\right)$ directly adjacent to the quartz vein with the lowest recorded $\delta^{18} \mathrm{O}(-1.2 \%)$. The rest of the leucogranite samples have whole rock $\delta^{18} \mathrm{O}$ values a few \%o on either side of the boundary between I-type and S-type granitoids. The Tsirub Gneiss (mean $=10.6 \%$ ) has slightly higher whole rock $\delta^{18} \mathrm{O}$ values compared to the biotite gneiss $($ mean $=9.1 \%)$. Both, however, fall well within the field of primary whole rock $\delta^{18} \mathrm{O}$ values previously reported for orthogneiss (Figure 11, Table S4).

7.2. Mineral Reactions and Mass Transfer. The types of replacement reactions most prevalent in the KMZ is growth of muscovite, chlorite, and feldspar. Whereas chlorite growth is restricted to localised areas, sericitization is seen throughout the shear zone. K-feldspar and plagioclase growth also occur throughout the shear zone; however, pervasive K-feldspar enrichment is only found in localised zones (Figures 3 and $4(d))$. The breakdown of feldspar and biotite in the presence of water to form muscovite, neoblasts of feldspar, and quartz has been reported from other midcrustal granitoid-hosted shear zones $[10,52,76]$ and conforms well with the general trend observed in the bulk rock geochemistry with gains of $\mathrm{SiO}_{2}, \mathrm{~K}_{2} \mathrm{O}$, and $\mathrm{Na}_{2} \mathrm{O}$ and loss of $\mathrm{Fe}_{2} \mathrm{O}_{3}, \mathrm{MgO}$, and $\mathrm{CaO}$. The reduction in $\mathrm{Fe}_{2} \mathrm{O}_{3}, \mathrm{MgO}$, and $\mathrm{CaO}$ may also be due to the breakdown of the minor epidote and amphiboles observed in some of the low-strain gneisses. The replacement of feldspar by muscovite leads to a volume reduction which would have increased the porosity and permeability and allowed continued fluid flow [77]. If the available fluid volumes would have remained low, however, the feldspar-to-muscovite reaction may halt, even reverse, with phyllosilicates dissolving and feldspar precipitating [9]. This may explain why the increase in phyllosilicate content with increasing strain seems to be impeded towards the highest strain in local shear zone cores. 
The replacement of most minerals by chlorite leads to a volume increase, and is therefore favoured at lower confining pressures [9]. Chlorite did, nonetheless, grow adjacent to many ultramylonites (Figures 2 and 4(a)), suggesting that these locations, characterised by the greatest strain gradients, may have been areas of higher porosity. These large strain gradients are defined by a gradual grain size reduction over $\mathrm{mm}$ to $\mathrm{cm}$ distances, partially due to retrograde metamorphic reactions, which potentially induced a deformation mechanism switch from dominantly dislocation creep in quartz and intragranular fracturing of feldspar to grain size sensitive creep [57]. Grain size sensitive creep allows for grain boundary sliding, creep caviation, dissolution, and precipitation, dynamically creating a permeable porosity [14]. Grain scale cavitation has experimentally been shown to have the capability to trigger runaway fault ruptures [75], and may be another way to allow the precipitation of coarse-grained chlorite, epidote, and K-feldspar adjacent to the ultramylonites.

In the KMZ, there is little to no correlation between the inferred mass change of the sampled rocks and their whole rock $\delta^{18} \mathrm{O}$ value (Figure 13), and furthermore, total relative mass changes are minor (Figure 9) and the rock samples across the shear zones retain the effect of different protoliths, with little variation in whole rock $\delta^{18} \mathrm{O}$ values (Figure 10). All of this suggest that fluid/rock ratios were low in the KMZ during deformation. This is in agreement with Diener et al. [45], who suggested that fluid/rock ratios of only $0.05-0.1$ are necessary to ensure complete rehydration and fluid saturation of the KMZ if fluid uptake is assumed to be efficient. The lack of correlation between mass change and whole rock $\delta^{18} \mathrm{O}$ values (Figure 13) also means that there is no simple relationship between mass change and extent of isotope exchange.

7.3. Effects on Fault Mechanics. The high-grade metamorphic rocks in which the KMZ developed would have been dry and relatively impermeable prior to initiation of KMZ shearing. It is therefore likely that deformation preceded fluid flow and not the other way around [45]. Deformation will thus have had to initiate without the weakening that retrograde reactions may facilitate. However, as fluids preferentially flow into deforming zones in the early stages of ductile deformation [78], and ductile shear zones can experience a pressure-induced dilatancy that promotes fluid flow into and along them [79] once a shear zone is active, progressive weakening and strain accumulation would favour progressive localisation of fluid flow and deformation, as proposed for the KMZ by Rennie et al. [47], Diener et al. [45], and Stenvall et al. [57]. Previous studies on the KMZ have postulated that shearing would initially have been enhanced on preexisting, well-oriented, fabrics or around stress risers such as the central leucogranite body [45,47]. This hypothesis is strengthened by the fact that the high-strain zones in area $\mathrm{D}$ seem to be localised where the preexisting migmatitic fabric was favourably oriented to shearing (Figure 4(c)). Furthermore, as deformation occurred at $T$ just above the frictional-viscous transition, downward propagation of earthquake ruptures from the brittle crust above may have transiently increased the differential stress, strain rate, and permeability in the KMZ throughout its evolution [71, 73]. The high thermal gradient of the KMZ and the consequent shorter distance to the overlying seismogenic zone strengthens this postulate. Compared to prograde metamorphic settings, where veins are abundant, the relative lack of veins and the inferred low fluid volumes in the KMZ suggest that elevated fluid pressures did not contribute significantly to either embrittlement or the creation of pathways for fluid infiltration.

At these early stages of shear zone evolution, at the conditions of shearing in the $\mathrm{KMZ}\left(450-480^{\circ} \mathrm{C}, 270-420 \mathrm{MPa}\right)$, deformation would have occurred by frictional-viscous flow, with crystal-plastic quartz and frictional feldspar governing the rheology [57]. At this stage, creep cavitation $[14,16]$ and grain boundary dissolution porosity [80] would potentially have provided the permeable porosity needed for fluid flow to infiltrate the shear zone and initiate retrograde reactions. As reported by Milke et al. [81], only a very small amount of $\mathrm{H}_{2} \mathrm{O}$ (on the order of a few ppm) is needed to enhance the growth rates of transport-controlled reactions, which in itself may produce nanoscale porosity [82]. The retrograde reactions would have induced weakening by the replacement of strong minerals by weaker phyllosilicates and by reducing the grain size through growth of new finegrained minerals (Figures 4, 5, and 6; [57]). In shear zones where replacement reactions were more extensive, weakening by phyllosilicate growth has been inferred to widen the shear zone [83]. In contrast, the localised deformation and transition to grain size sensitive creep in the KMZ may be a feature of shear zones where limited fluid flow and associated replacement reactions occurred.

The weakness of phyllosilicates is well known [84], and the presence of phyllosilicates is a common way to invoke weakness in shear zones $[9,32,85,86]$. The fine grain size on the other hand elevates the importance of diffusion [78, 87] and enhances grain boundary sliding due to the low cohesion between the new grain boundaries [8]. Grain boundary sliding in turn, together with continued nucleation of neoblasts in the dynamic porosity caused by creep cavitation, leads to second-phase pinning restricting grain growth. With progressive deformation, this promotes grain size sensitive creep as the main deformation mechanism (Fliervoet et al., 1997; [13, 57]). Therefore, as the highest-strained rocks in the KMZ do not contain large amounts of phyllosilicates, nor are the existing phyllosilicates interconnected (Figure 7(b)), the weakening due to the breakdown of strong mineral phases into weaker phyllosilicates only seems to have played a secondary role. The more significant weakening caused by the addition of fluids appears to have been its contribution to grain size sensitive deformation mechanisms. This includes retrograde metamorphic reactions and nucleation of new phases, as observed in the KMZ in porphyroclast stress shadows and the fine-grained polyphase mixtures.

In active retrograde faults, like the San Andreas Fault Zone, the Alpine Fault, the Haiyuan Fault, and the North Anatolian Fault, there are recent records of a range of seismic styles, from steady, plate boundary rate creep, through transient aseismic slip, to intermittent swarms of seismically detectable tremors [88-90] as well as low-resistivity zones at depth [35, 37]. Such low-stress drop events are believed 
to represent mixed frictional-viscous deformation at conditions of low effective stresses, sensitive to small perturbations $[91,92]$. The zones of low resistivity are therefore often interpreted to reflect fluid presence from which weakness is inferred, usually in the form of high pore fluid pressures ([30], [92]). Although an addition of fluids will result in weakening and the creation of conditions susceptible for tremor and low-frequency earthquakes, we caution the jump to high fluid pressure. Fluid volumes in retrograde settings are most likely low and externally derived, requiring a permeable network, and therefore hydrostatic fluid pressure conditions are more likely. Whereas high fluid pressure is an appropriate explanation for features such as tectonic tremor and low-frequency earthquakes in prograde metamorphic settings where a fluid source is readily available, the same cannot be said about retrograde settings. In retrograde settings, a fluid presence at the tremor source is more likely to induce the required weakening by facilitating retrograde reactions and grain size sensitive deformation mechanisms as suggested here for the KMZ.

\section{Conclusion: Sources and Effects of Fluids in Retrograde Shear Zones}

Although the host rocks of retrograde faults commonly, due to their high-grade metamorphic history, are dehydrated and relatively impermeable [27], they commonly exhibit retrograde mineral assemblages, suggesting a synkinematic fluid presence [32-34]. Due to the dehydrated nature of the host rocks, the sources for these fluids need to be external to the faults. In the KMZ, isotope compositions of rocks and quartz veins do not exclude any specific reservoir as a potential fluid source; however, they do require that at least some of the fluid was of meteoric origin, and precipitated quartz at high temperature (Figure 11). This requires a permeability pathway, which may have been created by downward propagation of earthquakes from the brittle crust above. The signs of brittle deformation in the KMZ are few and far apart; however, this is in accordance with the low and localised fluid volumes envisaged for the shear zone based on our geochemical analyses, which indicate little resetting of protolith whole rock $\delta^{18} \mathrm{O}$ values and minor local mass changes $(-39$ to $+11 \%$ and $-4.5 \%$ on average).

Even minimal volumes of fluid in a retrograde fault can induce weakening by facilitating retrograde reactions, such as growth of chlorite and muscovite at the expense of feldspar, biotite, and amphiboles. In the KMZ, weakening initially occurred by breakdown of feldspars and growth of chlorite and muscovite, which subsequently aligned to form interconnected weak networks. Continued strain localisation, beyond the weak, interconnected networks of phyllosilicates, shows that the weakening effect of fluids by promoting diffusion creep and grain size sensitive deformation mechanisms is even greater than the weakening effect by facilitation of retrograde reactions [57]. Reactions do, however, contribute to reducing and maintaining fine grain sizes by the pinning effect caused by the nucleation of neoblasts $[93,94]$. Niemeijer [95] suggests that earthquakes originating elsewhere on a fault would be rapidly arrested when encountering a foliated part of a fault deforming by frictional-viscous flow, and that the pulse of elevated slip velocity would lead to grain size reduction. This grain size reduction would destroy the foliation and the potential weakness it represents. However, we build on these suggestions and propose, based on our observations, that this could in fact lead to further weakening, in the presence of fluids that facilitate grain size sensitive diffusion creep at sufficiently high $T$.

These findings imply that the range of seismic styles recently reported for active retrograde faults, like the San Andreas Fault Zone, the Alpine Fault, the Haiyuan Fault, and the North Anatolian Fault [35, 37, 88-90], may not require high fluid pressures but could alternatively arise from other local weakening mechanisms that are easier to achieve in retrograde settings. In fact, high fluid pressures seem unlikely in retrograde settings, as potential free fluid would be consumed by retrograde reactions until a fluid-saturated mineral assemblage is formed. We emphasise that in the case of the KMZ, the addition of only small volumes of fluids induced drastic weakening by facilitating retrograde reactions and grain size sensitive deformation mechanisms.

\section{Data Availability}

The geochemical data used to support the findings of this study are included within the supplementary information files.

\section{Conflicts of Interest}

The authors declare that there is no conflict of interest regarding the publication of this paper.

\section{Acknowledgments}

We thank D. Wilson at the University of Cape Town and A. Oldroyd at Cardiff University for sample preparation. The support of D. Muir at Cardiff University's Electron Microbeam Facility, and the help of S. Roopnarain with the oxygen isotopes, are gratefully acknowledged. Constructive comments from P. Bons significantly improved the manuscript. This project has received funding from the European Research Council under the Horizon 2020 Framework Programme (Grant agreement 715836 "MICA"). C. Stenvall is funded by a Cardiff University College of Physical Sciences and Engineering Studentship.

\section{Supplementary Materials}

The supplementary materials include a table (Table S1) of all samples with $\delta^{18} \mathrm{O}$ values, tables of compositions (Tables S2), tables with isocon calculations (Table S3), and additional isocons to those shown in the main paper (Figure S1). A table containing data of para- and orthogneiss $\delta^{18} \mathrm{O}$ values from previous studies is provided separately in a .xlsx file (Table S4). (Supplementary Materials)

\section{References}

[1] W. F. Brace and D. L. Kohlstedt, "Limits on lithospheric stress imposed by laboratory experiments," Journal of Geophysical Research: Solid Earth, vol. 85, no. B11, pp. 6248-6252, 1980. 
[2] R. Bürgmann and G. Dresen, "Rheology of the lower crust and upper mantle: evidence from rock mechanics, geodesy, and field observations," Annual Review of Earth and Planetary Sciences, vol. 36, no. 1, pp. 531-567, 2008.

[3] Å. Fagereng and J. Biggs, "New perspectives on 'geological strain rates' calculated from both naturally deformed and actively deforming rocks," Journal of Structural Geology, vol. 125, pp. 100-110, 2019.

[4] T. Ingleby and T. J. Wright, "Omori-like decay of postseismic velocities following continental earthquakes," Geophysical Research Letters, vol. 44, no. 7, pp. 3119-3130, 2017.

[5] S. H. Kirby, "Rock mechanics observations pertinent to the rheology of the continental lithosphere and the localization of strain along shear zones," Tectonophysics, vol. 119, no. 1-4, pp. 1-27, 1985.

[6] D. L. Kohlstedt, B. Evans, and S. J. Mackwell, "Strength of the lithosphere: constraints imposed by laboratory experiments," Journal of Geophysical Research: Solid Earth, vol. 100, no. B9, pp. 17587-17602, 1995.

[7] M. K. Hubbert and W. W. Rubey, "Role of fluid pressure in mechanics of overthrust faulting," Geological Society of America Bulletin, vol. 70, no. 2, pp. 115-166, 1959.

[8] S. H. White and R. J. Knipe, "Transformation- and reactionenhanced ductility in rocks," Journal of the Geological Society, vol. 135, no. 5, pp. 513-516, 1978.

[9] R. P. Wintsch, R. Christoffersen, and A. K. Kronenberg, "Fluidrock reaction weakening of fault zones," Journal of Geophysical Research: Solid Earth, vol. 100, no. B7, pp. 13021-13032, 1995.

[10] J. Hippertt and F. D. Hongn, "Deformation mechanisms in the mylonite/ultramylonite transition," Journal of Structural Geology, vol. 20, no. 11, pp. 1435-1448, 1998.

[11] E. Oliot, P. Goncalves, K. Schulmann, D. Marquer, and O. Lexa, "Mid-crustal shear zone formation in granitic rocks: constraints from quantitative textural and crystallographic preferred orientations analyses," Tectonophysics, vol. 612613, pp. 63-80, 2014.

[12] J. D. F. Gerald and H. Stünitz, "Deformation of granitoids at low metamorphic grade. I: reactions and grain size reduction," Tectonophysics, vol. 221, no. 3-4, pp. 269-297, 1993.

[13] R. Kilian, R. Heilbronner, and H. Stünitz, "Quartz grain size reduction in a granitoid rock and the transition from dislocation to diffusion creep," Journal of Structural Geology, vol. 33, no. 8, pp. 1265-1284, 2011.

[14] F. Fusseis, K. Regenauer-Lieb, J. Liu, R. M. Hough, and F. de Carlo, "Creep cavitation can establish a dynamic granular fluid pump in ductile shear zones," Nature, vol. 459, no. 7249, pp. 974-977, 2009.

[15] M. A. Lopez-Sanchez and S. Llana-Fúnez, "A cavitation-seal mechanism for ultramylonite formation in quartzofeldspathic rocks within the semi-brittle field (Vivero fault, NW Spain)," Tectonophysics, vol. 745, pp. 132-153, 2018.

[16] L. Menegon, F. Fusseis, H. Stünitz, and X. Xiao, "Creep cavitation bands control porosity and fluid flow in lower crustal shear zones," Geology, vol. 43, no. 3, pp. 227-230, 2015.

[17] J. P. Platt, "Rheology of two-phase systems: a microphysical and observational approach," Journal of Structural Geology, vol. 77, pp. 213-227, 2015.

[18] S.-I. Karato, M. S. Paterson, and J. D. FitzGerald, "Rheology of synthetic olivine aggregates: influence of grain size and water," Journal of Geophysical Research: Solid Earth, vol. 91, no. B8, pp. 8151-8176, 1986.
[19] J. Tullis and R. A. Yund, "Hydrolytic weakening of experimentally deformed Westerly granite and Hale albite rock," Journal of Structural Geology, vol. 2, no. 4, pp. 439-451, 1980.

[20] S. A. Peacock, "Fluid processes in subduction zones," Science, vol. 248, no. 4953, pp. 329-337, 1990.

[21] Å. Fagereng and J. F. A. Diener, "Non-volcanic tremor and discontinuous slab dehydration," Geophysical Research Letters, vol. 38 , no. 15, 2011.

[22] Å. Fagereng, J. F. A. Diener, F. Meneghini, C. Harris, and A. Kvadsheim, "Quartz vein formation by local dehydration embrittlement along the deep, tremorgenic subduction thrust interface," Geology, vol. 46, no. 1, pp. 67-70, 2017.

[23] F. Meneghini and J. C. Moore, "Deformation and hydrofracture in a subduction thrust at seismogenic depths: the Rodeo Cove thrust zone, Marin Headlands, California," Geological Society of America Bulletin, vol. 119, no. 1-2, pp. 174-183, 2007.

[24] K. Ujiie, H. Saishu, Å. Fagereng et al., "An explanation of episodic tremor and slow slip constrained by crack-seal veins and viscous shear in subduction mélange," Geophysical Research Letters, vol. 45, no. 11, pp. 5371-5379, 2018.

[25] Å. Fagereng and J. F. A. Diener, "San Andreas Fault tremor and retrograde metamorphism," Geophysical Research Letters, vol. 38, no. 23, 2011.

[26] M. Guiraud, R. Powell, and G. Rebay, " $\mathrm{H}_{2} \mathrm{O}$ in metamorphism and unexpected behaviour in the preservation of metamorphic mineral assemblages," Journal of Metamorphic Geology, vol. 19, no. 4, pp. 445-454, 2001.

[27] N. H. S. Oliver, "Review and classification of structural controls on fluid flow during regional metamorphism," Journal of Metamorphic Geology, vol. 14, no. 4, pp. 477-492, 1996.

[28] V. Tenczer, R. Powell, and K. Stuwe, "Evolution of $\mathrm{H}_{2} \mathrm{O}$ content in a polymetamorphic terrane: the Plattengneiss Shear Zone (Koralpe, Austria)," Journal of Metamorphic Geology, vol. 24, no. 4, pp. 281-295, 2006.

[29] A. B. Thompson, "Fluid-absent metamorphism," Journal of the Geological Society, vol. 140, no. 4, pp. 533-547, 1983.

[30] J. R. Rice, "Chapter 20 Fault stress states, pore pressure distributions, and the weakness of the San Andreas fault," International Geophysics, vol. 51, pp. 475-503, 1992.

[31] T. Stern, D. Okaya, S. Kleffmann, M. Scherwath, S. Henrys, and F. Davey, Geophysical Exploration and Dynamics of the Alpine Fault Zone, American Geophysical Union, 2007.

[32] S. P. Jefferies, R. E. Holdsworth, C. A. J. Wibberley et al., "The nature and importance of phyllonite development in crustalscale fault cores: an example from the Median Tectonic Line, Japan," Journal of Structural Geology, vol. 28, no. 2, pp. 220 235, 2006

[33] D. Wallis, G. E. Lloyd, R. J. Phillips, A. J. Parsons, and R. D. Walshaw, "Low effective fault strength due to frictionalviscous flow in phyllonites, Karakoram Fault Zone, NW India," Journal of Structural Geology, vol. 77, pp. 45-61, 2015.

[34] C. A. Butler, R. E. Holdsworth, and R. A. Strachan, "Evidence for Caledonian sinistral strike-slip motion and associated fault zone weakening, Outer Hebrides Fault Zone, NW Scotland," Journal of the Geological Society, vol. 152, no. 5, pp. 743-746, 1995.

[35] A. A. Ozacar and G. Zandt, "Crustal structure and seismic anisotropy near the San Andreas Fault at Parkfield, California," Geophysical Journal International, vol. 178, no. 2, pp. 1098-1104, 2009. 
[36] E. Türkoğlu, M. Unsworth, İ. Çağlar, V. Tuncer, and Ü. Avşar, "Lithospheric structure of the Arabia-Eurasia collision zone in eastern Anatolia: magnetotelluric evidence for widespread weakening by fluids?," Geology, vol. 36, no. 8, pp. 619-622, 2008.

[37] P. E. Wannamaker, G. R. Jiracek, J. A. Stodt et al., "Fluid generation and pathways beneath an active compressional orogen, the New Zealand Southern Alps, inferred from magnetotelluric data," Journal of Geophysical Research: Solid Earth, vol. 107, no. B6, 2002.

[38] R. Kerrich, T. E. la Tour, and L. Willmore, "Fluid participation in deep fault zones: evidence from geological, geochemical, and ${ }^{18} \mathrm{O} /{ }^{16} \mathrm{O}$ relations," Journal of Geophysical Research: Solid Earth, vol. 89, no. B6, pp. 4331-4343, 1984.

[39] P. O. Koons and D. Craw, "Evolution of fluid driving forces and composition within collisional orogens," Geophysical Research Letters, vol. 18, no. 5, pp. 935-938, 1991.

[40] C. D. Menzies, D. A. H. Teagle, D. Craw et al., "Incursion of meteoric waters into the ductile regime in an active orogen," Earth and Planetary Science Letters, vol. 399, pp. 1-13, 2014.

[41] P. M. Fulton and D. M. Saffer, "Potential role of mantlederived fluids in weakening the San Andreas Fault," Journal of Geophysical Research: Solid Earth, vol. 114, no. B7, 2009.

[42] W. P. Irwin and I. Barnes, "Effect of geologic structure and metamorphic fluids on seismic behavior of the San Andreas fault system in central and northern California," Geology, vol. 3, no. 12, pp. 713-716, 1975.

[43] D. Zhao, M. Santosh, and A. Yamada, "Dissecting large earthquakes in Japan: role of arc magma and fluids," Island Arc, vol. 19, no. 1, pp. 4-16, 2010.

[44] B. M. Kennedy, Y. K. Kharaka, W. C. Evans et al., "Mantle fluids in the San Andreas fault system, California," Science, vol. 278, no. 5341, pp. 1278-1281, 1997.

[45] J. F. A. Diener, Å. Fagereng, and S. A. J. Thomas, "Mid-crustal shear zone development under retrograde conditions: pressure-temperature-fluid constraints from the Kuckaus Mylonite Zone, Namibia," Solid Earth, vol. 7, no. 5, pp. 1331-1347, 2016.

[46] M. P. A. Jackson, High-grade metamorphism and migmatization of the Namaqua Metamorphic Complex around Aus in the southern Namib Desert, South West Africa, [Ph.D. thesis], University of Cape Town, 1976.

[47] S. F. Rennie, Å. Fagereng, and J. F. A. Diener, "Strain distribution within a km-scale, mid-crustal shear zone: the Kuckaus Mylonite Zone, Namibia," Journal of Structural Geology, vol. 56, pp. 57-69, 2013.

[48] S. M. Hartman, S. R. Paterson, G. J. Holk, and J. D. Kirkpatrick, "Structural and hydrothermal evolution of a strike-slip shear zone during a ductile-brittle transition, Sierra Nevada, CA," Journal of Structural Geology, vol. 113, pp. 134-154, 2018.

[49] A. M. McCaig, S. M. Wickham, and H. P. Taylor Jr., "Deep fluid circulation in alpine shear zones, Pyrenees, France: field and oxygen isotope studies," Contributions to Mineralogy and Petrology, vol. 106, no. 1, pp. 41-60, 1990.

[50] H. P. Taylor, "Water/rock interactions and the origin of $\mathrm{H}_{2} \mathrm{O}$ in granitic batholiths," Journal of the Geological Society, vol. 133, no. 6, pp. 509-558, 1977.

[51] K. O’Hara, "Fluid flow and volume loss during mylonitization: an origin for phyllonite in an overthrust setting, North Carolina U.S.A.," Tectonophysics, vol. 156, no. 1-2, pp. 21-36, 1988.

[52] L. Spruzeniece and S. Piazolo, "Strain localization in brittleductile shear zones: fluid-abundant vs. fluid-limited conditions (an example from Wyangala area, Australia)," Solid Earth, vol. 6, no. 3, pp. 881-901, 2015.

[53] R. M. Miller, "Namaqua Metamorphic Complex," in The Geology of Namibia, R. M. Miller, Ed., Geological Survey of Namibia, Windhoek, 2008.

[54] R. J. Thomas, A. L. D. Agenbacht, D. H. Cornell, and J. M. Moore, "The Kibaran of southern Africa: tectonic evolution and metallogeny," Ore Geology Reviews, vol. 9, no. 2, pp. 131-160, 1994.

[55] H. Blignault, M. Jackson, G. Beukes, and D. Toogood, "The Namaqua Tectonic Province in South West Africa," Bulletin of the Precambrian Research Unit, University of Cape Town, South Africa, vol. 15, pp. 29-47, 1974.

[56] J. F. A. Diener, R. W. White, K. Link, T. S. Dreyer, and A. Moodley, "Clockwise, low-P metamorphism of the Aus granulite terrain, southern Namibia, during the Mesoproterozoic Namaqua Orogeny," Precambrian Research, vol. 224, pp. 629-652, 2013.

[57] C. A. Stenvall, Å. Fagereng, and J. F. A. Diener, "Weaker than weakest: on the strength of shear zones," Geophysical Research Letters, vol. 46, no. 13, pp. 7404-7413, 2019.

[58] C. Harris and J. Vogeli, "Oxygen isotope composition of garnet in the Peninsula Granite, Cape Granite Suite, South Africa: constraints on melting and emplacement mechanisms," South African Journal of Geology, vol. 113, no. 4, pp. 401-412, 2011.

[59] J. A. Grant, "The isocon diagram; a simple solution to Gresens' equation for metasomatic alteration," Economic Geology, vol. 81, no. 8, pp. 1976-1982, 1986.

[60] A. F. Glazner and J. M. Bartley, "Volume loss, fluid flow and state of strain in extensional mylonites from the central Mojave Desert, California," Journal of Structural Geology, vol. 13 , no. 5 , pp. $587-594,1991$.

[61] K. C. Condie and A. K. Sinha, "Rare earth and other trace element mobility during mylonitization: a comparison of the Brevard and Hope Valley shear zones in the Appalachian Mountains, USA," Journal of Metamorphic Geology, vol. 14, no. 2, pp. 213-226, 1996.

[62] Y. Rolland, S. Cox, A.-M. Boullier, G. Pennacchioni, and N. Mancktelow, "Rare earth and trace element mobility in mid-crustal shear zones: insights from the Mont Blanc Massif (Western Alps)," Earth and Planetary Science Letters, vol. 214, no. 1-2, pp. 203-219, 2003.

[63] J. E. Streit and S. F. Cox, "Fluid infiltration and volume change during mid-crustal mylonitization of Proterozoic granite, King Island, Tasmania," Journal of Metamorphic Geology, vol. 16, no. 2, pp. 197-212, 2004.

[64] E.-A. Zen, "Aluminum enrichment in silicate melts by fractional crystallization: some mineralogic and petrographic constraints," Journal of Petrology, vol. 27, no. 5, pp. 1095-1117, 1986.

[65] R. L. Gresens, "Composition-volume relationships of metasomatism,” Chemical Geology, vol. 2, pp. 47-65, 1967.

[66] Y. Matsuhisa, J. R. Goldsmith, and R. N. Clayton, "Oxygen isotopic fractionation in the system quartz-albite-anorthitewater," Geochimica et Cosmochimica Acta, vol. 43, no. 7, pp. 1131-1140, 1979.

[67] H. Craig, "Isotopic variations in meteoric waters," Science, vol. 133, no. 3465, pp. 1702-1703, 1961.

[68] T. Raimondo, C. Clark, M. Hand, J. Cliff, and R. Anczkiewicz, "A simple mechanism for mid-crustal shear zones to record surface-derived fluid signatures," Geology, vol. 41, no. 6, pp. 711-714, 2013. 
[69] C. Clark, M. Hand, K. Faure, and A. S. Mumm, "Up-temperature flow of surface-derived fluids in the mid-crust: the role of pre-orogenic burial of hydrated fault rocks," Journal of Metamorphic Geology, vol. 24, no. 5, pp. 367-387, 2006.

[70] L. M. Lobato, J. M. A. Forman, W. S. Fyfe, R. Kerrich, and R. L. Barnett, "Uranium enrichment in Archaean crustal basement associated with overthrusting," Nature, vol. 303, no. 5914, pp. 235-237, 1983.

[71] A. M. McCaig, "Deep fluid circulation in fault zones," Geology, vol. 16, no. 10, pp. 867-870, 1988.

[72] A. Barker, D. Bennett, A. Boyce, and A. Fallick, "Retrogression by deep infiltration of meteoric fluids into thrust zones during late-orogenic rapid unroofing," Journal of Metamorphic Geology, vol. 18, no. 3, pp. 307-318, 2000.

[73] S. Ellis and B. Stöckhert, "Elevated stresses and creep rates beneath the brittle-ductile transition caused by seismic faulting in the upper crust," Journal of Geophysical Research: Solid Earth, vol. 109, no. B5, 2004.

[74] B. Jamtveit, A. Petley-Ragan, S. Incel et al., "The effects of earthquakes and fluids on the metamorphism of the lower continental crust," Journal of Geophysical Research: Solid Earth, vol. 124, no. 8, pp. 7725-7755, 2019.

[75] B. A. Verberne, J. Chen, A. R. Niemeijer et al., "Microscale cavitation as a mechanism for nucleating earthquakes at the base of the seismogenic zone," Nature Communications, vol. 8, no. 1, p. 1645, 2017.

[76] Y. Park, S.-H. Yoo, and J.-H. Ree, "Weakening of deforming granitic rocks with layer development at middle crust," Journal of Structural Geology, vol. 28, no. 5, pp. 919-928, 2006.

[77] D. Rumble and F. S. Spear, "Oxygen-isotope equilibration and permeability enhancement during regional metamorphism," Journal of the Geological Society, vol. 140, no. 4, pp. 619-628, 1983.

[78] A. Beach, "Retrogressive metamorphic processes in shear zones with special reference to the Lewisian complex," Journal of Structural Geology, vol. 2, no. 1-2, pp. 257-263, 1980.

[79] N. S. Mancktelow, "How ductile are ductile shear zones?," Geology, vol. 34, no. 5, pp. 345-348, 2006.

[80] M. A. Billia, N. E. Timms, V. G. Toy, R. D. Hart, and D. J. Prior, "Grain boundary dissolution porosity in quartzofeldspathic ultramylonites: implications for permeability enhancement and weakening of mid-crustal shear zones," Journal of Structural Geology, vol. 53, pp. 2-14, 2013.

[81] R. Milke, G. Neusser, K. Kolzer, and B. Wunder, "Very little water is necessary to make a dry solid silicate system wet," Geology, vol. 41, no. 2, pp. 247-250, 2013.

[82] O. Plümper, A. Botan, C. Los, Y. Liu, A. Malthe-Sørenssen, and B. Jamtveit, "Fluid-driven metamorphism of the continental crust governed by nanoscale fluid flow," Nature Geoscience, vol. 10, no. 9, pp. 685-690, 2017.

[83] P. Goncalves, E. Oliot, D. Marquer, and J. A. D. Connolly, "Role of chemical processes on shear zone formation: an example from the Grimsel metagranodiorite (Aar massif, Central Alps)," Journal of Metamorphic Geology, vol. 30, no. 7, pp. 703-722, 2012.

[84] W. T. Shea and A. K. Kronenberg, "Strength and anisotropy of foliated rocks with varied mica contents," Journal of Structural Geology, vol. 15, no. 9-10, pp. 1097-1121, 1993.

[85] J. Imber, R. E. Holdsworth, C. A. Butler, and G. E. Lloyd, "Fault-zone weakening processes along the reactivated Outer
Hebrides Fault Zone, Scotland," Journal of the Geological Society, vol. 154, no. 1, pp. 105-109, 1997.

[86] R. J. McAleer, D. L. Bish, M. J. Kunk et al., "Reaction softening by dissolution-precipitation creep in a retrograde greenschist facies ductile shear zone, New Hampshire, USA," Journal of Metamorphic Geology, vol. 35, no. 1, pp. 95-119, 2017.

[87] E. H. Rutter, "A discussion on natural strain and geological structure-the kinetics of rock deformation by pressure solution.," Philosophical Transactions of the Royal Society of London. Series A, Mathematical and Physical Sciences, vol. 283, no. 1312, pp. 203-219, 1997.

[88] R. Jolivet, T. Candela, C. Lasserre, F. Renard, Y. Klinger, and M.-P. Doin, "The burst-like behavior of aseismic slip on a rough fault: the creeping section of the Haiyuan Fault, China," Bulletin of the Seismological Society of America, vol. 105, no. 1, pp. 480-488, 2015.

[89] D. R. Shelly, “A 15 year catalog of more than 1 million lowfrequency earthquakes: tracking tremor and slip along the deep San Andreas Fault," Journal of Geophysical Research: Solid Earth, vol. 122, no. 5, pp. 3739-3753, 2017.

[90] A. G. Wech, C. M. Boese, T. A. Stern, and J. Townend, “Tectonic tremor and deep slow slip on the Alpine fault," Geophysical Research Letters, vol. 39, no. 10, 2012.

[91] R. M. Skarbek, A. W. Rempel, and D. A. Schmidt, "Geologic heterogeneity can produce aseismic slip transients," Geophysical Research Letters, vol. 39, no. 21, 2012.

[92] A. M. Thomas, R. M. Nadeau, and R. Bürgmann, "Tremor-tide correlations and near-lithostatic pore pressure on the deep San Andreas fault," Nature, vol. 462, no. 7276, pp. 1048-1051, 2009.

[93] M. Herwegh, J. Linckens, A. Ebert, A. Berger, and S. H. Brodhag, "The role of second phases for controlling microstructural evolution in polymineralic rocks: a review," Journal of Structural Geology, vol. 33, no. 12, pp. 1728-1750, 2011.

[94] M. Krabbendam, J. L. Urai, and L. J. van Vliet, "Grain size stabilisation by dispersed graphite in a high-grade quartz mylonite: an example from Naxos (Greece)," Journal of Structural Geology, vol. 25, no. 6, pp. 855-866, 2003.

[95] A. R. Niemeijer, "Velocity-dependent slip weakening by the combined operation of pressure solution and foliation development," Scientific Reports, vol. 8, no. 1, p. 4724, 2018. 